\title{
ANAIS DO II SIMPÓSIO DE GENÉTICA DO DELTA DO PARNAÍBA
}

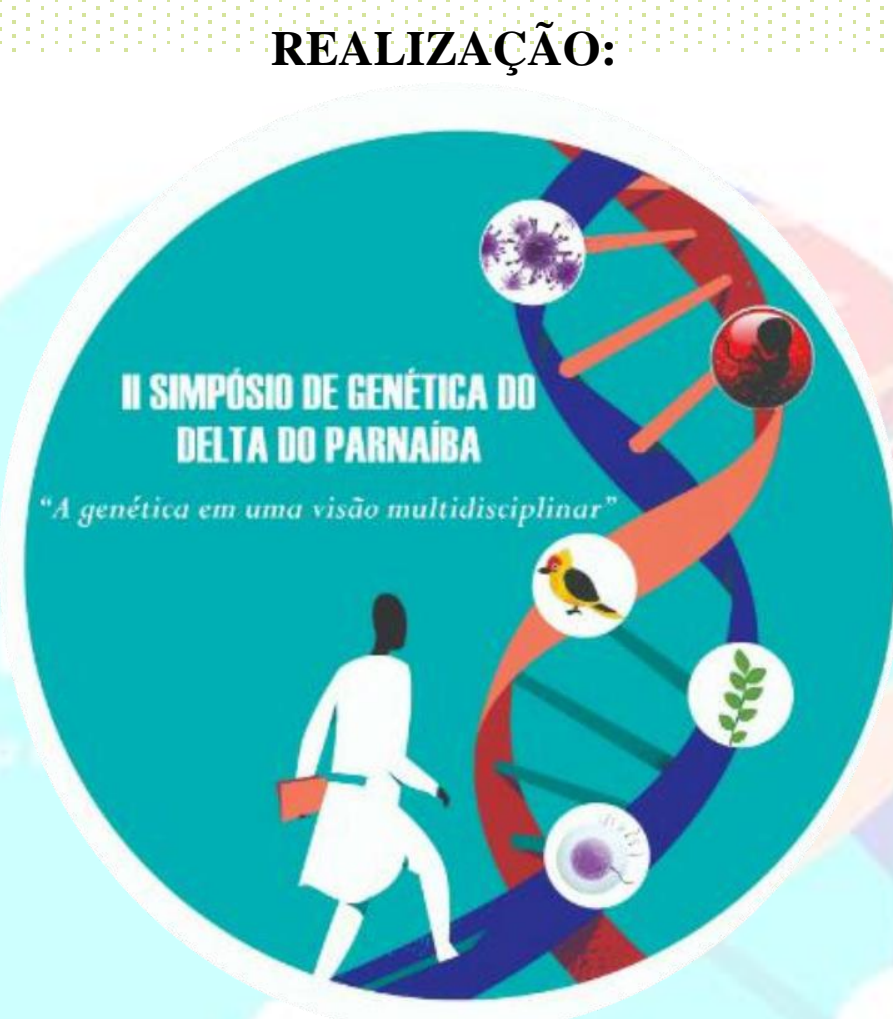

APOIO:

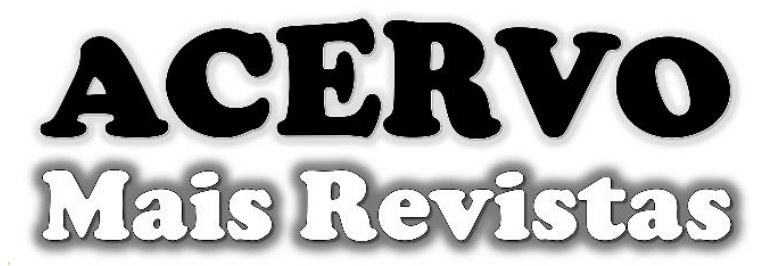

As publicações mais rápidas do país!

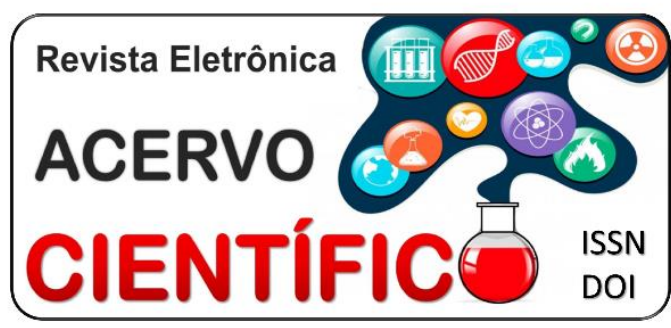




\title{
Anais do II Simpósio de Genética do Delta do Parnaíba
}

\section{FICHA TÉCNICA}

II SIMPÓSIO DE GENÉTICO DO DELTA DO PARNAIIBA

Realizado nos dias 24,25 e 26 de outubro de 2019.

Local: Universidade Federal do Delta do Parnaíba - Parnaíba-PI

\section{APRESENTAÇÃO}

O II Simpósio de Genética do Delta do Parnaíba é uma iniciativa dos discentes da Liga Acadêmica de Genética -LiAGen da UFPI CMRV, juntamente com docentes da área, o qual pretende reunir acadêmicos de vários cursos, pesquisadores e profissionais da saúde e áreas afins, que tenham o interesse em estreitar o conhecimento no vasto campo da genética. Com apresentação de temas em todas as áreas da Genética (Humana, Animal, Vegetal, de Microrganismos e Educação).

\section{Presidente}

France Keiko Nascimento Yoshioka

\author{
Coordenador de Marketing e Propaganda \\ Liga Acadêmica de Genética - LiAGen
}

\section{Coordenador (a) Financeira}

Liga Acadêmica de Genética - LiAGen

Amanda Teixeira Gonçalves Bárbara Rebeca de Macedo Pinheiro Deosdethe Macedo Gonçalves Junior

Eduarda Pereira de Paiva Freitas

Hinaira Brunna Gomes Cavalcante José Humberto da Cunha Joyce de Jesus Santos

Maria Gabrielly Gonçalves da Silva Sousa

Maria Julia Rebeche Cornélio Oliveira Maryna Reis

Naira Celeste da Costa Ferreira

Paloma Maria de Sousa Araújo Pedro Vitor Cerqueira Paiva Renata Pereira Nolêto

Romério de Oliveira Lima Filho Roseline Marques dos Santos Ygor Victor Ferreira Pinheiro

\section{Organização:}

Alana Maria Gomes da Silva Ana Klara Rodrigues Alves Brenda Nascimento Dias Francisco das Chagas Araújo Mota Filho Geovana Ferraz de Souza John Arlley Sousa Pinho de Lira José Rodolpho de Sousa Lopes Larisse Ellen Linhares Martins Lisrhanna Alves de Aguiar Maria Adrielly Gomes de Souza Paulo Roberto Carneiro Gomes Rubens Renato de Sousa Carmo

\section{Parnaíba-PI}




\section{Anais do II Simpósio de Genética do Delta do Parnaíba}

\section{SUMÁRIO}

Bioprospecção do Gênero Bauhinia L. (FABACEAE): Uma Projeção Biotecnológica para Marcadores Moleculares ISSR e RAPD

Polimorfismos Genéticos que Afetam o Metabolismo de Medicamentos Utilizados na Terapia Anticâncer Pulmonar

A Formação de Anticorpos Anti-fator VIII no Tratamento da Hemofilia A: Uma Revisão Breve da Literatura.

A Relação entre a Genética e a Esquizofrenia

Aconselhamento Genético como Ferramenta Assistencial para Portadores de Síndrome de

Down e suas Famílias.

Análise das Técnicas de Biologia Molecular na Investigação Forense: Uma Revisão da

Literatura

Anemias Hereditárias: As Alterações Estruturais e as Deficiência de Síntese

Aplicação de Modelo Didático Síntese Proteica - Tradução: Relato de Experiência.

Aplicação Potencial do Genoma de Tubarões para a Cura do Câncer: Uma Revisão de

Literatura

Avaliação da Atividade Antioxidante do Extrato de Gengibre ante o Estresse Oxidativo em Saccharomyces cerevisiae.

Avaliação dos Polimorfismos Genéticos de Genes Relacionados ao Tabaco e a

Susceptibilidade ao Desenvolvimento do Câncer

Bioensaio com Artemia salina (Leach) para a Detecção da Toxicidade do Extrato Etanólico da Casca de Sterculia striata a. St. Hil. \& Naudin

Caracterização e Correlação do Omeprazol no Processo de Morte Celular - Uma Revisão

Sistemática

O Impacto nas Redes Sociais da Atividade de uma Liga Acadêmica de Genética

Eliminação do Genoma Viral do HIV do Material Genético Humano pelo CRISPR-Cas9:

Uma Revisão Bibliográfica.

Erosão Genética em Espécies Vegetais no Brasil: Revisão de Literatura ……………………....30

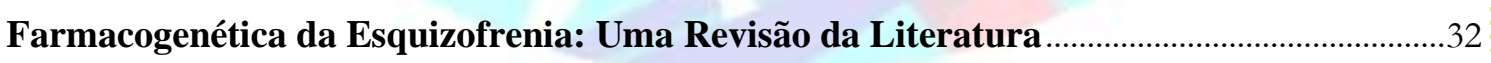

Gene P63 e o Controle de Qualidade de Gametas Femininos ....................................................

Importância do Diagnóstico das Hemoglobinopatias em Gestantes_...................................

Diagnóstico de Infecções por Clostridioides difficile a partir da Técnica de PCR Quantitativa: Uma Revisão Bibliográfica.

Hemocromatose Hereditária Juvenil a partir da Mutação do gene HAMP: uma revisão bibliográfica

Principais Marcadores Genéticos Utilizados no Diagnóstico da Doença de Alzheimer ......44 
Monitoramento de Marcadores Moleculares de Resistência Antimalárica: Uma Revisão Bibliográfica

Mecanismos Epigenéticos Envolvidos no Desenvolvimento do Lúpus Eritematoso

Sistêmico: Uma Revisão Bibliográfica

O Impacto dos Polimorfismos da CYP2D6 no Tratamento do Câncer de Mama com Tamoxifeno.

O Papel do Enfermeiro no Aconselhamento Genético: Uma Breve Revisão de Literatura 52 A Importância do PCNA como Marcador Tumoral em Pacientes com Câncer Ovariano .54 Química Prebiótica e a Formação das Primeiras Moléculas Informacionais: Uma Revisão Bibliográfica

O Uso de Recursos Didáticos por Professores de Biologia no Ensino de Genética

Relação entre Matemática e Leis de Mendel em uma Escola Pública de Parnaíba-PI.

Reposição de Estrogênio e o Risco de Câncer Endometrial em Pacientes com Polimorfismo no Citocromo p450.

Screening Toxicológico do Extrato Etanólico da Flor de Pityrocarpa moniliformis (Benth) através do Bioensaio Artemia salina (Leach)

Diversidade Gênica em Isolados do Gênero Leishmania: Uma Revisão Literária

“Jogo da Memória: Que Herança é essa?” como Instrumento Facilitador no Ensino de Genética

Relação da Endogamia com Doenças Genéticas na Região Nordeste: Uma Revisão Bibliográfica 


\section{Bioprospecção do Gênero Bauhinia L. (FABACEAE): Uma Projeção Biotecnológica para Marcadores Moleculares ISSR e RAPD}

${ }^{1}$ Davi Nascimento Costa; ${ }^{2}$ Renata Brito Reis $;{ }^{3}$ Ivanilza Moreira de Andrade.

${ }^{1}$ Graduando (a) em Ciências Biológicas na Universidade Federal do Piauí - UFPI; ${ }^{2}$ Pósgraduanda em Biotecnologia (PPGBIOTEC) na Universidade Federal do Piauí- UFPI; ${ }^{3}$ Professora do Programa de Pesquisa e Pós-graduação em Biotecnologia - PPGBiotec, UFPI.

\section{RESUMO}

No Brasil, as espécies do gênero Bauhinia são utilizadas pela comunidade como hipoglicemiante. As folhas são utilizadas como antidiabéticas e empregadas por comunidades tradicionais como tratamento para doenças gastrointestinais e parasitoses. Objetivou-se com este estudo realizar prospecção científica sobre Bauhinia e, através do perfil quantitativo das publicações e verificar as que utilizam marcadores moleculares ISRR e RAPD. A prospecção foi realizada com base em periódicos depositados nas bases de dados Web of Science, SCOPUS, Scielo e PubMed. Os descritores utilizados foram: "Bauhinia and marker", "Bauhinia and RAPD" e "Bauhinia and ISSR". Utilizaram-se os campos de pesquisa "título" e/ou "resumo". A pesquisa foi realizada em setembro de 2019 para todas as bases.: Os resultados demonstram que no que se refere aos descritores "Bauhinia and marker" encontraram-se trabalhos relacionados a outros marcadores como os SSR o que se avalia como indicativo para a utilização destes marcadores em pesquisas relacionadas ao gênero. O Brasil foi o país que mais publicou pesquisas $(n=9)$. Ao utilizar os termos "Bauhinia and RAPD", foram encontrados três estudos. As áreas de publicações foram Silvicultura $(n=1)$, Biomedicina $(n=1)$ e Botânica $(n=1)$ e os países que publicaram trabalhos relacionados ao marcador RAPD envolvendo o gênero, foram Índia $(\mathrm{n}=2)$ e Egito $(\mathrm{n}=1)$. Quando se utilizou os descritores "Bauhinia and ISSR" encontrou-se um total de três publicações e os únicos países publicadores foram China $(n=2)$ e Índia $(n=1)$, as áreas de publicações estão relacionadas à Botânica $(n=2)$ e Ecologia e Ciências ambientais $(n=1)$. Conclui-se que, o Brasil carece de estudos e publicações relacionadas ao gênero, por ser um país com grande biodiversidade, estudar a variabilidade e diversidade genética de plantas utilizadas na medicina popular, torna-se crucial para a conservação, melhoramento genético e manutenção das espécies.

\section{Palavras-chave: Caatinga; Potencial Tecnológico; Prospecção.}

\section{Referências}

DOMINGOS, A. H.; JÚNIOR, L. C. Plantas medicinais: patas-de-vaca. Série Produtor Rural, Piracicaba, n. 60, 2016.

FARIAS, F. L. et al. Avaliação da atividade antibacteriana de extrato etanólico da Bauhinia forficata L. Diversitas Journal, v. 3, n. 2, p. 402-411, 2018.

NOGUEIRA, A. C.O; SABINO, C. V.S. Revisão do Gênero Bauhinia abordando aspectos científicos das espécies Bauhinia forficata Link e Bauhinia variegata L. de interesse para a indústria farmacêutica. Revista Fitos, v. 7, n. 02, 2013. 


\section{Polimorfismos Genéticos que Afetam o Metabolismo de Medicamentos Utilizados na Terapia Anticâncer Pulmonar}

${ }^{1}$ Samara Marques de Oliveira; ${ }^{1}$ Paulo Roberto Carneiro Gomes; ${ }^{1}$ Wesley Rodrigues da Silva; ${ }^{1}$ Rubens Renato de Sousa Carmo; ${ }^{2}$ Victor Lucas Ribeiro Lopes; ${ }^{2}$ Even Herlany Pereira Alves.

${ }^{1}$ Graduando (a) em Biomedicina na Universidade Federal do Piauí - UFPI; ${ }^{2}$ Mestrando (a) em Biotecnologia na Universidade Federal do Piauí - UFPI.

\section{RESUMO}

INTRODUÇÃO: O câncer de pulmão, principalmente o subtipo câncer de pulmão de células não pequenas, é a principal causa de morte relacionada ao câncer em todo o mundo. A quimioterapia à base de platina é o tratamento padrão para a maioria dos pacientes com esse tipo de câncer. No entanto, a toxicidade induzida pelo tratamento à base de platina dificulta o uso clínico, ademais inúmeros polimorfismos têm sido associados à suscetibilidade a doença além de influenciar no tratamento cancerígeno. OBJETIVO: Realizar um levantamento bibliográfico acerca dos polimorfismos que estão afetando a terapia anticâncer ou desenvolvendo toxicidade associado ao câncer de pulmão. METODOLOGIA: Foi realizado uma busca de dados bibliográficos nas plataformas eletrônicas: PubMed, Cochrane e Bireme, utilizando os descritores em português e inglês: farmacogenética, polimorfismo genético e neoplasia pulmonar. Os artigos publicados nos últimos 5 anos, que não fossem revisões bibliográficas e que explanassem a respeito do tema no título e/ou resumo foram incluídos no presente trabalho, artigos que iam contra os critérios de inclusão foram exclusos. RESULTADOS E DISCUSSÃ O: A busca sistemática de dados resultou em 54 artigos nas três bases utilizadas (PubMed=52, Cochrane=1 e Bireme=1), após remoção de duplicatas e aplicação dos critérios de exclusão, foram inclusos na revisão bibliográfica 14 estudos, dos quais os pacientes seguiam tratamento à base de platina. Os artigos mostraram que os pacientes com neoplasia pulmonar ao possuir polimorfismos nos genes: IL16 rs7170924-GG, ERCC1, C118T-Alelo T e genótipo ERCC2 rs50872-CC, RAC1rs836554, rs4720672 e rs12536544 apresentaram maior risco de toxicidade quimioterápica à base de platina. Agrupando os dados contidos nos artigos, a análise de toxicidade do subtipo também revelou que o ERCC2 rs50872CC genótipo e alelo IL16 rs7170924-T, o POLR2E rs3787016-HOTTIP rs3807598, o MATE1 rs2289669, o CASC8 rs10505477 e o polimorfismo em OCT2 rs316019 foram associados à toxicidade hematológica. Além disso, o ABCC2 rs717620, ANRIL rs10120688 e rs1333049, H19 rs2107425 foram associados à resposta quimioterápica à base de platina, ou seja, podem ser potenciais biomarcadores clínicos para prever o risco de câncer de pulmão e a resposta à quimioterapia à base de platina. CONCLUSÃO: Existem inúmeros polimorfismos de produtos gênicos que interferem negativamente e aumentam a toxidade de medicamentos utilizados na terapia anticâncer, no entanto, eles podem servir como um possível marcador de risco para o diagnóstico de câncer de pulmão e poderia ser usado para prever a resposta e a toxicidade do tratamento à base de platina em pacientes com câncer de pulmão.

Palavras-chave: Farmacogenética; Polimorfismo genético; Neoplasia pulmonar. 


\section{Referências}

HAMILTON, Gerhard, RATH, Barbara. Pharmacogenetics of platinum-based chemotherapy in non-small cell lung cancer: predictive validity of polymorphisms of ERCC1. Expert opinion on drug metabolism \& toxicology, v. 14, n. 1, p. 17-24, 2018.

QIAN, Chen-Yue et al. Associations of genetic polymorphisms of the transporters organic cation transporter 2 (OCT2), multidrug and toxin extrusion 1 (MATE1), and ATP-binding cassette subfamily $\mathrm{C}$ member 2 (ABCC2) with platinum-based chemotherapy response and toxicity in non-small cell lung cancer patients. Chinese journal of cancer, v. 35, n. 1, p. 85, 2016.

ZENKE, Yoshitaka et al. Successful treatment with afatinib after grade 3 hepatotoxicity induced by both gefitinib and erlotinib in EGFR mutation-positive nonsmall cell lung cancer. Lung Cancer, v. 99, p. 1-3, 2016.

ZOU, Ting et al. Rho GTPases: RAC1 polymorphisms affected platinum-based chemotherapy toxicity in lung cancer patients. Cancer chemotherapy and pharmacology, v. 78, n. 2, p. 249-258, 2016. 


\section{A Formação de Anticorpos Anti-fator VIII no Tratamento da Hemofilia A: Uma Revisão Breve da Literatura}

Ana Klara Rodrigues Alves ${ }^{1}$; Barbara Beatriz Lira da Silva ${ }^{1}$; Ana Kamila Rodrigues Alves $^{2}$; Ana Karla Rodrigues Alves 3 ; Francisco Artur e Silva Filho ${ }^{4}$; Kelly Sivocy Sampaio Teixeira ${ }^{5}$.

${ }^{1}$ Acadêmicas de Enfermagem da Universidade Estadual do Piauí-UESPI; ${ }^{2}$ Acadêmica de Fisioterapia pela Universidade Federal do Piauí-UFDPar; ${ }^{3}$ Graduada em Biomedicina pela Universidade Federal do Piauí-UFPI; ${ }^{4}$ Professor adjunto da Universidade Estadual do Piauí; ${ }^{5}$ Professora temporária da Universidade Estadual do Piauí.

\section{RESUMO}

INTRODUÇÃO: A hemofilia A (HA) é uma coagulopatia recessiva ligada ao cromossomo $\mathrm{X}$ causada pela deficiência ou disfunção da glicoproteína plasmática denominada fator VIII (FVIII) que afeta 1:5000 meninos nascidos vivos, sendo um distúrbio genético relacionado ao sexo. Portadores de HA podem apresentar sangramento em qualquer órgão após lesão vascular. As manifestações hemorrágicas mais comuns são a hemartrose e as articulações mais afetadas são joelhos, cotovelos, tornozelos, ombros e punho. O tratamento de HA é baseado na reposição do FVIII, seja recombinante ou derivada do plasma, requerendo infusões intravenosas de concentrados de FVIII exógeno. OBJETIVO: Analisar a literatura científica relatando a formação de anticorpos contra o Fator VIII no tratamento da hemofilia A. MÉTODOLOGIA: Trata-se de uma revisão breve da literatura realizada na base de dados SCIELO e via Biblioteca Virtual em Saúde (BVS). Foram encontrados 125 artigos, sendo selecionados 7, a partir o cruzamento simultâneo entre os descritores "Fator VIII" e "Inibidores dos Fatores de Coagulação Sanguínea". Neste estudo, introduziram-se artigos escritos na língua portuguesa, inglesa e espanhola, publicados entre os anos 2014 e 2018. RESULTADOS E DISCUSSÃO: A formação de anticorpos anti-FVIII é o evento mais complicador no tratamento da HA com concentrados de FVIII. Cerca de 5\% a 30\% dos pacientes com hemofilia A desenvolvem anticorpo inibidor anti-FVIII, que são do tipo anticorpos imunoglobulina $\mathrm{G}$ (IgG). Tais anticorpos anti-FVIII, também chamados inibidores, neutralizam a atividade procoagulante do FVIII no plasma através do bloqueio funcional de epítopos (sítios antigênicos) da proteína e diminuem a eficácia do tratamento. Pouco se conhece sobre a etiologia do desenvolvimento dos inibidores de FVIII. Embora, a ocorrência de inibidores reflete uma resposta imune alogênica à administração repetida da proteína exógena. Os inibidores neutralizam o fator VIII e aumentam morbidade e mortalidade de pacientes com HA quando comparados àqueles que não portam inibidores. No entanto, o tipo de concentração de fator VIII, a intensidade e duração também pode influenciar a incidência de inibidores. CONCLUSÃO: A presença de inibidor anti-FVIII pode representar alterações nos esquemas terapêuticos de pacientes com hemofilia e explicam possíveis complicações clínicas nesses pacientes, os mesmos podem necessitar de infusões terapêuticas mais frequentes e de indução de imunotolerância, que se faz administrando doses muito altas de FVIII por períodos prolongados, para que o sistema imune passe a tolerá-lo.

Palavras-chave: Fator VIII, Tratamento, Inibidores dos Fatores de Coagulação Sanguínea. 


\section{Referências}

MARTÍNEZ-SÁNCHEZ, L. M. et al. Hemofilia: abordaje diagnóstico y terapéutico.. Revisión bibliográfica. Rev. Fac. Nac. Salud. Pública. v. 36, n.2, p.85-93, 2018.

MILLER, C. H. Characteristics of hemophilia patients with factor VIII inhibitors detected by prospective screening. Am J Hematol. v.90, n.10, p. 871-6, 2015.

RANAL, D. Hemofilia: tratamento e profilaxia. [Tese]. Marília, Sp: Programa de Aprimoramento Profissional - Secretaria de Estado da Saúde- Fundap, Faculdade de Medicina de Marília, 2014.

ROSINEIDE A. Carvalho, R. A, et al. Incidence of factor VIII inhibitory antibodies in patients with hemophilia A seen at HEMOCE, Ceará, Brazil. J Bras Patol Med Lab, v.52, n. 6, p. 382-386, 2016. 


\title{
A Relação entre a Genética e a Esquizofrenia
}

\author{
Alana Maria Gomes da Silva ${ }^{1}$, Gabrielly Oliveira Silva ${ }^{2}$, Carolina Alcântara Teixeira ${ }^{3}$. \\ ${ }^{1,2,3}$ Graduanda em Psicologia pela Universidade Federal do Delta do Parnaíba - \\ UFDPar.
}

\section{RESUMO}

Introdução: A esquizofrenia acomete mais de 21 milhões de pessoas em todo o mundo, sendo considerada um problema de saúde pública. Sua manifestação se dá principalmente pela presença de sintomas positivos (alucinações verbais e visuais, delírios, mudança no processo de pensamento, percepções e afetos) e sintomas negativos (embotamento afetivo-volitivo, perdas cognitivas e sintomas depressivos). Há indícios de que a esquizofrenia é um transtorno que possui origem multifatorial, em que fatores genéticos e ambientais parecem estar ligados a um aumento das chances de desenvolvê-la. Objetivo: Verificar a influência da genética no desenvolvimento do transtorno esquizofrênico. Métodos: As buscas foram realizadas nas seguintes bases de dados: Scielo e Lilacs. Utilizando como descritores "esquizofrenia e genética" e "aspectos genéticos da esquizofrenia", dos artigos encontrados apenas quatro entraram na presente revisão. Resultados e Discussão: Ter um familiar com esquizofrenia é um dos fatores de risco mais congruentes e significativos para o desenvolvimento do transtorno. Parentes de primeiro grau de um paciente com esquizofrenia possuem cerca de $10 \%$ de chance de desenvolver o transtorno, ser irmão gêmeo monozigótico é o maior fator de risco isolado para desenvolvê-la, a sua hereditariedade é em média 0,83, uma das taxas mais altas entre os transtornos psicológicos. Várias regiões genômicas têm sido indicadas como suspeitas de possuir genes com predisposição para o transtorno, genes como RGS4 (Regulator of G-protein signalling 4), DRD3 (Dopamine Receptor D3), DRD5 (Dopamine Receptor D5), entre outros, parecem estar relacionados a esquizofrenia, porém, essas supostas regiões de suscetibilidade variam de família para família e de estudo para estudo, sugerindo que o transtorno possui um alto grau de heterogeneidade. Esses dados demonstram que existe uma correlação entre a genética do indivíduo e o desencadeamento do transtorno e quanto mais próximo o grau de parentesco maior são as chances, porém, o ambiente também influencia de maneira decisiva no surgimento da esquizofrenia. Conclusão: Estudos comprovam que a genética possui influência no desenvolvimento do transtorno, porém, vista de maneira isolada ela não determina o desenvolvimento da esquizofrenia. A genética possui uma relação determinante, mas, é a interação entre os fatores ambientais e genéticos que fazem com que um indivíduo desenvolva o transtorno. A compreensão dos fatores genéticos associados à esquizofrenia é fundamental, ao passo que contribuem para o cuidado com o paciente e embasam o aconselhamento genético para orientar o melhor tratamento e gerar qualidade de vida para o indivíduo.

\section{Palavras-chave: Esquizofrenia; Genética; Ambiente.}

\section{Referências}

ARARIPE NETO, Ary Gadelha de Alencar; BRESSAN, Rodrigo Affonseca; BUSATTO FILHO, Geraldo. Fisiopatologia da esquizofrenia: aspectos atuais. Rev. psiquiatr. clín., São Paulo, v. 34, supl. 2, p. 198-203, 2007. Available from http://dx.doi.org/10.1590/S0101-60832007000800010. 
OJOPI, Elida P. Benquique et al . O genoma humano e as perspectivas para o estudo da esquizofrenia. Rev. psiquiatr. clín., São Paulo, v. 31, n. 1, p. 9-18, 2004.

http://dx.doi.org/10.1590/S0101-60832004000100003.

PINTO, Jeizziani Aparecida Ferreira et al . Prevalence of polymorphisms in the ANKK1, DRD2, DRD3 genes and metabolic syndrome in refractory schizophrenia. Rev. Latino-Am. Enfermagem, Ribeirão Preto, v. 26, e2983, 2018 . http://dx.doi.org/10.1590/1518-8345.2222.2983.

SILVA, Regina Cláudia Barbosa da. Esquizofrenia: uma revisão. Psicol. USP, São Paulo, v. 17, n. 4, p. 263-285, 2006 .http://dx.doi.org/10.1590/S010365642006000400014. 


\title{
Aconselhamento Genético como Ferramenta Assistencial para Portadores de Síndrome de Down e suas Famílias
}

\author{
${ }^{1}$ Paloma Maria de Sousa Araujo; ${ }^{1}$ Airton Lucas Sousa dos Santos; ${ }^{1}$ Ana Clara de Moura \\ Guimarães; ${ }^{1}$ José Humberto da Cunha; ${ }^{1}$ Vanessa dos Santos Brito; ${ }^{2}$ Renata Canalle. \\ ${ }^{1}$ Graduando (a) em Biomedicina pela Universidade Federal do Piauí - UFPI; \\ ${ }^{2}$ Professora Adjunta em Biomedicina na Universidade Federal do Piauí - UFPI.
}

\section{RESUMO}

INTRODUÇÃO: A Síndrome de Down (SD) corresponde a mutação cromossômica, relativa à trissomia do 21 , sendo a mais comum detectada durante a triagem neonatal, que gera um conjunto de malformações que afetam vários órgãos e desencadeiam fenótipos básicos, como a deficiência intelectual, a micrognatia e a implantação baixa das orelhas. Ademais, a SD sendo diagnosticada durante a gravidez, favorece aos pais um melhor entendimento e melhoria na vivência deste portador ao nascer. Ainda, o acompanhamento na gravidez e após o nascimento advindo do Aconselhamento Genético (AG), é realizado por uma equipe multiprofissional, que informam e orientam acerca de riscos de recorrência da síndrome, prognóstico, estratégias de tratamento e prevenção, e recomendações para os consulentes que procurem o serviço. Por isso, o acesso ao AG pela população é primordial, pois o entendimento da doença tem o impacto direto no tratamento e vida dos portadores e familiares. OBJETIVO: Avaliação de artigos científicos, para indicar o impacto que o Aconselhamento Genético desencadeia na vivência de portadores de Síndrome de Down e suas respectivas famílias. METODOLOGIA: Fez-se uma revisão bibliográfica nas bases de dados Scielo, Lilacs e PubMed por meio das terminologias cadastradas nos Descritores em Ciências da Saúde, compostas por "Aconselhamento Genético", "cuidado pré-concepcional" e "Síndrome de Down". Assim, foram definidos critérios de inclusão que relacionam a importância de facultar aos pacientes de SD e parentes o serviço de Aconselhamento Genético de forma gratuita a fim de promover a saúde. Por outro lado, foram excluídos os estudos que destoavam deste panorama, que não correlacionavam a consulta com melhoria de pacientes com doença genética. RESULTADOS E DISCUSSÃO: A partir da pesquisa foram encontrados treze artigos, que discorrem sobre a importância do AG em casos de trissomia do 21, no diagnóstico e vida do indivíduo. Como também, demonstram que cerca de $80 \%$ dos casos, as crianças não realizavam tratamento prévio, e após o processo de consulta, $90 \%$ dos mesmos começaram a investir em processos terapêuticos. Desencadeando assim, uma melhora no prognóstico, tratamento e diminuição da gravidade da patologia, proporcionando o acompanhamento adequado para a integração dos mesmos na sociedade. CONCLUSÃO: O acesso ao AG pelos consulentes e pacientes é de suma relevância para melhoramento na vida dos mesmos diante a patologia. Dessa forma, torna-se imprescindível uma análise detalhada para efetivar os procedimentos de consultoria genética no sistema público durante os exames pré-natais a fim de promover saúde, e evitar negligência no tratamento desta síndrome.

Palavras-chave: Aconselhamento Genético, Cuidado pré-concepcional, Síndrome de Down.

\section{Referências}

MATA, PIGNATA. Síndrome de Down: Aspectos Históricos, Biológicos e Sociais, Goiás, 2014. 
MICHELLETO, et al. Adesão ao Tratamento de Aconselhamento Genético na Síndrome de Down, São Paulo. 2009.

PAIVA, et al. Síndrome de Down: Etiologia, Características e Impactos na Família, São Paulo. 2014 


\section{Análise das Técnicas de Biologia Molecular na Investigação Forense: Uma Revisão da Literatura}

${ }^{1}$ Fhillipe Ferreira Deodato da Silva; ${ }^{1}$ Wellia Adriany Bernardo Vieira Santos; ${ }^{1}$ Nicolle Barreira Maciel; ${ }^{1}$ Gustavo Oliveira Monteiro Alves, ${ }^{1}$ Jéssica Maria de Jesus Ferreira da Silva; ${ }^{2}$ Even Herlany Pereira Alves.

${ }^{1}$ Graduando (a) em Biomedicina na Universidade Federal do Piaú - UFPI; ${ }^{2}$ Pós graduanda em Biotecnologia na Universidade Federal do Piauí - UFPI.

\section{RESUMO}

INTRODUÇÃO: Nas ciências forenses, as técnicas de biologia molecular vêm se fortalecendo ao passar dos anos. Isso em função do desenvolvimento de novas técnicas e métodos eficazes para a detecção do DNA humano para fins forenses. O Brasil é um dos países onde mais ocorrem homicídios no mundo. Ainda assim apenas 5\% a 8\% deles são elucidados. Apenas em 2012 o Brasil passou a possuir um banco genético para a resolução de crimes. OBJETIVO: Avaliar a importância do uso das técnicas de biologia molecular na resolução de casos na ciência forense. METODOLOGIA: Realizou-se uma busca nos bancos de dados Medline, Pubmed e Google Scholar; os descritores utilizados foram: "técnicas", "genética", "forense", "application", foram selecionados artigos em Português e em Inglês, e excluídos aqueles que não concordavam com o tema e que não estavam disponíveis na íntegra. Após a aplicação dos critérios de exclusão foram encontrados 12 artigos. RESULTADOS E DISCUSSÃO: Dentre as técnicas de extração de DNA, a extração orgânica é o método mais tradicional na genética forense. A extração diferencial é outra técnica, onde obtém-se a fração espermática (FE), muito empregada em amostras provenientes de crimes sexuais. Uma das principais técnicas de biologia molecular utilizada na investigação forense é a reação em cadeia polimerase (PCR). A sensibilidade da PCR possibilita a utilização de pequenas amostras como saliva ou fios de cabelo, permitindo uma comparação com outras amostras previamente coletadas. A eletroforese capilar é outra técnica amplamente utilizada na área forense, que possibilita a inclusão de suspeitos de um crime, pois o DNA encontrado na vítima é comparado com o DNA dos mesmos, como ocorre com marcas de mordida ou presença de sêmen. $\mathrm{O}$ Southern Blot é uma técnica usada na identificação de polimorfismos, por meio de uma sequência de bases especificas. Restriction fragment length polymorphism (RFLP) obtidos com uma determinada sonda podem ser utilizados no estabelecimento de "FingerPrint" de DNA, que permite a diferenciação entre dois indivíduos distintos. Outra técnica é a de sequenciamento de nova geração (NGS), esta é atual e se mostra promissora nos casos em que a amostra está degradada, e poderá permitir a análise simultânea do DNA autossômico padrão, DNA mitocondrial e marcadores cromossômicos $\mathrm{X}$ e $\mathrm{Y}$. CONCLUSÃO: Ressalta-se a importância do uso dessas técnicas de biologia molecular no estudo forense, para que este possa oferecer resultados precisos e seguros na identificação de suspeitos e vítimas, auxiliando à justiça na elucidação de crimes.

\section{Palavras-chave: Desoxirribonucleases; Genética forense; Reação em Cadeia da Polimerase.}

\section{Referências}

L.M.Silva,et al. Finger printing of cell lines by directed amplification of minisatelliteregion DNA (DAMD) .Brazilian Journal of Medical and Biological Research. Belo Horizonte, MG, Brasil. 2001. 
Luciana CD, Lissiane MCVP. DNA forense artigo de revisão. Saúde \& Ambiente em Revista. Duque de Caxias. 2007.

MariaJ AC, et al. Next generation sequencing: anapplication in forensic sciences? Annals of Human Biology. 2017. 


\title{
Anemias Hereditárias: As Alterações Estruturais e as Deficiência de Síntese
}

\author{
${ }^{1}$ Maria Rikelly Frota Aguiar; ${ }^{1}$ Daniele Alcoforado Costa; ${ }^{1}$ Sandiely Santos da Silva; ${ }^{2}$
} Josiane da Silva Costa ${ }^{3}$ Antonia Luzia Lima do Nascimento.

${ }^{1}$ Graduando (a) em Biomedicina na Universidade Federal do Piauí - UFPI; ${ }^{2}$ Graduando (a) em Biologia na Universidade Federal do Piauí - UFPI; ${ }^{3}$ Biomédica pela Universidade Federal do Piauí - UFPI.

\section{RESUMO}

INTRODUÇÃO: As anemias hereditárias fazem parte do grupo de doenças genéticas mais prevalentes no mundo, separadas em grupos, cada uma com sua complexidade. As hemoglobinopatias são anemias hereditárias, dentro delas há as alterações estruturais e as deficiências de síntese. Sendo as estruturais, a hemoglobina $\mathrm{C}$ e $\mathrm{S}$, já nas deficiências de síntese, engloba as talassemias ( $\alpha$-talassemia e $\beta$ - talassemia). Nas anemias hereditárias, vem crescendo o número de indivíduos homozigotos e heterozigotos. OBJETIVO: Mostrar quais são as anemias hereditárias e entender os seus grupos e a complexidade de cada um. METODOLOGIA: Foram avaliados artigos provenientes da fonte de dados da PubMed e Scielo tanto no idioma português como inglês utilizando descritores de buscas "doenças hereditárias" e "hemoglobinopatias" para entender os principais aspectos e fatores resultantes nas alterações moleculares. RESULTADOS E DISCUSSÃO: Na pesquisa foi percebido que a anemia falciforme é uma das doenças hematológicas mais comum em humanos, ocasionada pela substituição pontual da base nitrogenada timina (T) por adenina (A) possibilitando a substituição do aminoácido ácido glutâmico por valina, no sexto códon do éxon 1 no DNA do cromossomo 11, na posição seis da cadeia $\beta$, tendo como produto uma hemoglobina anormal por conta da modificação da estrutura molecular, denominada hemoglobina S. Que além de alterações físico-químicas na estrutura das hemácias, como formação de polímeros e poder deformatório adquirindo a forma de foice, o paciente ainda sofre por interferentes ambientais quando portadores de traço falciforme (hemoglobina AS), sendo acometidos por sequências de alterações estruturais e funcionais nos mais diversos sistemas do paciente. Em se tratando de talassemias, são anemias hemolíticas hereditárias microcíticas que se caracterizam por defeitos na síntese da hemoglobina, caracterizado por redução na produção de uma ou mais cadeias polipeptídicas de globina, são utilizadas as terminologias alfa e beta $(\alpha-$ talassemia e $\beta$-talassemia) na classificação. Com a pesquisa foi visto que a $\alpha$-talassemia pode ser hereditária ou adquirida. O diagnóstico de talassemia e hemoglobinopatias prioriza uma análise abrangente a partir de hemograma completo, análise de hemoglobina e estudos moleculares para identificar mutações nos genes da globina. CONCLUSÃO: As anemias hereditárias podem ser tanto estruturais, como também algum erro na síntese, este último, podendo ser de forma adquirida ou hereditária. É importante salientar, a relevância de saber se o indivíduo é heterozigoto ou homozigoto, pois isso afeta no grau da doença e no tratamento.

\section{Palavras-chave: Anemias Hereditárias; Genética; Hemoglobinopatias.}

\section{Referências}

ELO-REIS, Paulo R. et al. A importância do diagnóstico precoce na prevenção das anemias hereditárias. Revista Brasileira de Hematologia e Hemoterapia, [s.1.], v. 28, n. 2, p.149-152, jun. 2006. Elsevier BV. http://dx.doi.org/10.1590/s151684842006000200017 
NOGUEIRA, Raí N. et al. Clinical and laboratory repercussions in patient with hemoglobin SD-Punjab disease: a case report. Jornal Brasileiro de Patologia e Medicina Laboratorial, [s.1.], v. 53, n. 5, p.309-312, 2017. GN1 Genesis Network. http://dx.doi.org/10.5935/1676-2444.20170049

Zago, MA; Costa, FF; Bottura, C; Ione, IG. Hereditary hemoglobin screening disorders in a Brazilian population. Human Hereditary. 1983, 33:125-129. 


\title{
Aplicação de Modelo Didático Síntese Proteica - Tradução: Relato de Experiência
}

\author{
${ }^{1}$ Maria de Jesus Pereira Gomes; ${ }^{1}$ Dandara Maria Silva Araújo; ${ }^{2}$ Mateus Oliveira da \\ Cruz; ${ }^{3}$ Francilene Leonel Campos. \\ ${ }^{1}$ Graduanda em Licenciatura em Ciências Biológicas, Universidade Federal do Piauí - \\ UFPI; ${ }^{2}$ Licenciado em Ciências Biológicas pela UFPI; ${ }^{3}$ Professora Associada em \\ Licenciatura em Ciências Biológicas - UFPI.
}

\begin{abstract}
RESUMO
INTRODUÇÃO: A complexidade que envolve o ensino de biologia atrelada a elaboração e execução de aulas diferentes e empolgantes que estimulem a atenção e interesse dos alunos no processo ensino-aprendizagem e consequentemente que este seja de fato significativo, é hoje, o principal desafio dos professores. OBJETIVO: O presente trabalho objetivou relatar a aplicação do modelo didático "Síntese Proteica - Tradução" em turmas de $3^{\circ}$ ano do Ensino médio. METODOLOGIA: Este foi aplicado em uma escola pública da cidade de Parnaíba - PI de elaboração e aplicabilidade de modelo didático referente ao tema "Síntese Proteica", utilizando materiais de baixo custo. A aplicação do modelo didático juntamente com a abordagem do tema, permitiu aos alunos o manuseio das estruturas representativas dos componentes constituintes do processo de tradução da síntese proteica. As atividades foram desenvolvidas com duas turmas de $3^{\circ}$ ano, aqui mencionadas como 01 e 02 . Previamente foi aplicado um pré-teste aos alunos sobre seus conhecimentos prévios do assunto. Após a aplicação do modelo um pós-teste fora realizado. RESULTADOS: Durante o trabalho observou-se a heterogeneidade entre as turmas. A Turma 01, apresentou interesse e participação no decorrer da atividade desenvolvida. Os alunos desta turma apresentaram bom desenvolvimento no pré-teste. Demonstrando ser aptos a absorver o conteúdo, os estudantes fixaram sua atenção e interagiram quando aplicado o modelo didático contribuindo para desempenho ainda maior no pós-teste. Em relação à Turma 02, esta não apresentou interesse durante a aula e aplicação do modelo. Assim, colaborando para o baixo desempenho tanto no pré-teste como no pós-teste. De forma geral, pode-se notar que a aplicação do modelo didático contribuiu para uma maior interação dos alunos com o conteúdo, visto que as turmas puderam visualizar e manusear a representação de um processo molecular. O material aplicado foi viável para persuasão de questionamentos e compreensão da forma das estruturas e sequência dos acontecimentos. A partir do uso do modelo didático os alunos se tornaram mais ativos em sala de aula e se aproximaram do conhecimento abordado através da participação, argumentos e manuseio dos materiais. CONCLUSÃO: Este modelo didático foi eficiente em apresentar o tema síntese proteica tendo em vista a interação observada entre os alunos durante a aplicação. $\mathrm{O}$ uso de recursos, que permitem uma interação protagonista do aluno, tem como consequência um aumento na absorção do conteúdo e de rendimento, pois a utilização de modelos didáticos pode despertar nos alunos o interesse pela pesquisa, desenvolvendo habilidades e competências.
\end{abstract}

\section{Palavras-chave: Ensino; Aprendizagem; Genética.}

\section{Referêcias}

ALMEIDA, P. N. de. Educação Lúdica: técnicas e jogos pedagógicos. São Paulo: Loyola, 6 ed. 1990. 
CARVALHO, M. P. de. Critérios estruturantes para o ensino das Ciências. In:

CARVALHO, M. P. de. Ensino de Ciências: Unindo a Pesquisa e a Prática.1. ed. São Paulo: Thonson Pioneira, 2003.

GOLDSCHMIDT, A. I. et al. Despertando o Interesse por Charles. Darwin e pela Evolução Biológica através da Investigação Científica. Acta Scientiae, Canoas v.13, n. 2 , jul./dez. 2011.

KOVALICZN, R. A. O professor de Ciências e de Biologia frente as parasitoses comuns em escolares. 12p. Dissertação. (Mestrado em Educação). Universidade Estadual de Ponta Grossa, Ponta Grossa, 1999.

LIMA, M. E. C.C.; AGUIAR, O. G.; BRAGA, S. A. M. Ensinar Ciências. Presença Pedagógica, Belo Horizonte,v. 6, n.33, mai./jun. 2000. 


\title{
Aplicação Potencial do Genoma de Tubarões para a Cura do Câncer: Uma Revisão de Literatura
}

\author{
1Paulo Roberto Carneiro Gomes; ${ }^{3}$ André dos Santos Carvalho; ${ }^{1}$ Samara Marques de \\ Oliveira; ${ }^{2}$ Maria Débora Rodrigues da Rocha.; ${ }^{1}$ ohn Arlley Sousa Pinho de Lira; ${ }^{1}$ Hélio \\ Mateus Silva Nascimento. \\ ${ }^{1}$ Graduando (a) em Biomedicina na Universidade Federal do Piauí - UFPI; Graduanda \\ em ${ }^{2}$ Fisioterapia na Universidade Federal do Piauí - UFPI; ${ }^{3}$ Pós-graduando em Ciências \\ Biomédicas pela Universidade Federal do Piauí - UFPI.
}

\section{RESUMO}

INTRODUÇÃO: Tubarões prosperam nos oceanos há mais de 16 milhões de anos, o que os tornam criaturas extraordinárias e com diversas adaptações. Assim como os humanos, esses indivíduos vivem em média 75 anos e tal característica torna-os mais propensos a sofrer doenças ligadas ao envelhecimento celular, dentre elas o câncer. Através desses achados, pesquisadores vislumbram a descoberta de como tais genes interagem e esperam futuramente aplicar estas informações no tratamento de doenças ligadas ao envelhecimento celular. OBJETIVO: Analisar a literatura refletindo sobre as possibilidades da utilização de informações sobre a atuação dos genes de tubarões em terapias gênicas humanas e o impacto de tais descobertas na conservação ambiental de espécies. METODOLOGIA: Foram utilizados 7 artigos para esta revisão provenientes das bases: Google scholar, Pubmed e Medline. Os critérios de inclusão foram: artigos publicados nos últimos 5 anos em língua inglesa. Os descritores utilizados foram: Tubarões, genes e envelhecimento celular. RESULTADOS: O genoma do tubarão branco possui 41 pares de cromossomos $=82$, com um tamanho de $6,3 \mathrm{Gpb}$, duas vezes maior que o do ser humano. Apresenta um número de repetições de DNA superior a todas as espécies já estudadas, representando 58,55\%. Diversos genes estão associados à estabilidade do genoma, dentre estes a cascata ERK1/ERK2, sendo a taxa deste positiva em um dos trabalhos analisados. Um recente trabalho com tubarões brancos do pacífico demonstrou um elevado grau de variabilidade genética em microssatélites derivados do transcriptoma. Como a evolução molecular de tubarões é muito lenta, estudos relacionados a construção de microssatélites destas espécies reduzem os custos de outras pesquisas de variabilidade populacional, permitindo o avanço das mesmas em áreas comerciais. O sistema imunológico de tubarões já vem sendo estudado a algum tempo e pesquisas anteriores demonstram que os anticorpos destes organismos possuem uma capacidade excepcional de resistência, sugerindo o desenvolvimento de novos fármacos com efeitos antitumorais. Em 2017, uma patente com anticorpos para terapia do câncer foi publicada, o que reforça algo singular no sistema imune desses organismos. Há alguns anos, a indústria farmacêutica vem comercializando produtos derivados de tubarões como óleos e cápsulas de cartilagem para a prevenção do câncer, isso coloca esses animais na mira de caçadores, favorecendo um forte declínio das espécies nos últimos anos. CONCLUSÃO: Pesquisadores ressaltam que a continuidade de pesquisas moleculares com esses animais pode favorecer a preservação ambiental de espécies, no tocante em que novas medidas podem surgir, reforçando o controle de crimes ambientais.

\section{Palavras-chave: Tubarões; Genes; Neoplasias.}




\section{Referências}

BERNARD, Andrea M. et al. Transcriptome-Derived Microsatellites Demonstrate Strong Genetic Differentiation in Pacific White Sharks. Journal of Heredity, v. 109, n. 7, p. $771-779,2018$.

CAMARGO, Sâmia M. et al. Structure and genetic variability of the oceanic whitetip shark, Carcharhinus longimanus, determined using mitochondrial DNA. PloS one, v. 11, n. 5 , p. $\mathrm{e} 0155623,2016$.

HSU, Ellen. Assembly and expression of shark Ig genes. The Journal of Immunology, v. 196, n. 9, p. 3517-3523, 2016.

READ, Timothy D. et al. Draft sequencing and assembly of the genome of the world's largest fish, the whale shark: Rhincodon typus Smith 1828. BMC genomics, v. 18, n. 1, p. 532, 2017. 


\title{
Avaliação da Atividade Antioxidante do Extrato de Gengibre ante o Estresse Oxidativo em Saccharomyces cerevisiae
}

\author{
${ }^{1}$ John Arlley Sousa Pinho de Lira; ${ }^{2}$ Antonielly Campinho dos Reis, ${ }^{3}$ Rosália Maria \\ Tôrres de Lima; ${ }^{1}$ Matheus Pedrosa de Oliveira, ${ }^{4}$ Ana Maria Oliveira Ferreira da Mata; \\ ${ }^{2,5}$ Ana Amélia de Carvalho Melo Cavalcante. \\ ${ }^{1}$ Graduando em Biomedicina na Universidade Federal do Piauí - UFPI; Parnaíba, Piauí. \\ Brasil. ${ }^{2}$ Programa de Pós-graduação em Ciências Farmacêuticas. Laboratório de \\ Pesquisa em Genética Toxicológica - LAPGENIC; Universidade Federal do Piauí. \\ Teresina, Piauí. Brasil. ${ }^{3}$ IFPI- Instituto Federal do Piauí. ${ }^{4}$ Programa de Pós-graduação \\ em Biotecnologia - RENORBIO. Universidade Federal do Piauí. Teresina, Piauí. Brasil. \\ ${ }^{5}$ Programas de Pós-graduações em Ciências Farmacêuticas e Biotecnologia - \\ RENORBIO. Universidade Federal do Piauí. Teresina, Piauí. Brasil.
}

\section{RESUMO}

INTRODUÇÃO: O câncer é uma patologia multifatorial provocada principalmente por danos no DNA que podem ser ocasionados por estresse oxidativo. É caracterizado pela diferenciação e proliferação desordenada de células e é considerado a segunda causa de morte no mundo, com previsão de 600 mil casos para o biênio 2018-2019 no Brasil. Dentre seus tratamentos, há o uso de antineoplásicos convencionais que apresentam diversos efeitos colaterais e instabilidade genômica em células não neoplásicas. Frente a isso, surge a oportunidade de desenvolvimento de novos medicamentos baseados em produtos naturais que são facilmente disponíveis e acessíveis, além de possuírem diversas propriedades farmacológicas. O gengibre (Zingiber officinale), por exemplo, cujo extrato é utilizado em uma gama de enfermidades, como diabetes, doenças reumáticas e problemas estomacais, possui bioativos que demonstram diversas atividades farmacológicas, especialmente antioxidantes, anti-inflamatórias e antitumorais. OBJETIVO: Diante o exposto, este estudo tem por objetivo avaliar a atividade antioxidante do extrato de gengibre (EG) frente aos danos oxidativos induzidos pelo peróxido de hidrogênio $\left(\mathrm{H}_{2} \mathrm{O}_{2}\right)$ em Saccharomyces cerevisiae proficiente e mutadas em defesas antioxidantes. METODOLOGIA: Foi realizado o teste com seis linhagens de Saccharomyces cerevisiae (selvagem (SODWT); mutada em superóxido dismutase citoplasmática (SOD1); mutada em superóxido dismutase mitocondrial (SOD2); mutada em SOD1 e SOD2; em catalase (CAT1); e em CAT1 e SOD1) em pré-, co- e póstratamento com o EG $\left(5 \mu \mathrm{g} \cdot \mathrm{mL}^{-1}, 10 \mu \mathrm{g} \cdot \mathrm{mL}^{-1}\right.$ e $\left.20 \mu \mathrm{g} \cdot \mathrm{mL}^{-1}\right)$ e $\mathrm{H}_{2} \mathrm{O}_{2}(10 \mathrm{mM})$, por $48 \mathrm{~h}$ de incubação a $30^{\circ} \mathrm{C}$. Foi utilizado salina como controle negativo $(\mathrm{CN})$ e o $\mathrm{H}_{2} \mathrm{O}_{2}$ como positivo (CP). Após, foram mensurados os halos de inibição e os dados foram analisados estatisticamente $(\mathrm{p}<0,05)$. RESULTADOS: No pré-tratamento, o EG não eliminou a oxidação nas concentrações testadas, em todas as linhagens de $S$. cerevisiae usadas, quando comparado a $\mathrm{CN}$, porém apresentou atividade antioxidante, quando comparado a $\mathrm{CP}$, especialmente na concentração de $5 \mu \mathrm{g} \cdot \mathrm{mL}^{-1}(\mathrm{p}<0,05)$. Resultados similares foram observados tanto no co- quanto no pós-tratamento. CONCLUSÃO: O extrato de gengibre exibiu ação preventiva, antioxidante e reparativa nas três concentrações, em pré, pós e co-tratamento frente ao estresse oxidativo induzido por $\mathrm{H}_{2} \mathrm{O}_{2}$ nas seis linhagens de $S$. cerevisiae, tendo a menor concentração apresentado a melhor eficácia. Assim, fica evidenciado o potencial antioxidante do extrato de gengibre para futuros estudos a serem desenvolvidos na área, com o intuito de utilizar o EG como alternativa para o tratamento e prevenção do câncer.

Palavras-chaves: Gengibre; Antioxidante; Saccharomyces cerevisiae. 


\section{Referências}

EBRAHIMZADEH ATTARI, V.; MALEK MAHDAVI, A.; JAVADIVALA, Z; MAHLUJI, S.; ZUNUNI MANSINGH, D. P.; SALI, V. K.; VASANTHI, H. R. [6]Gingerol-induced cell cycle arrest, reactive oxygen species generation, and disruption of mitochondrial membrane potential are associated with apoptosis in human gastric cancer (AGS) cells. Journal of biochemical and molecular toxicology, p. e22206, 2018.

OLIVEIRA, G. L. S.; OLIVEIRA, F. R. A. M.; ALENCAR, M. V. O. B.; GOMES JÚNIOR, A. L.; SOUZA, A. A.; CAVALCANTE, A. A. C. M.; FREITAS, R. M. Evaluation of antioxidant capacity of the aqueous extract of Cynara scolymus L. (Asteraceae) in vitro and in Saccharomyces cerevisiae. African Journal of Pharmacy and Pharmacology, v. 7, n. 5, p. 136-147, 2014.

RAYAN, A.; RAIYN, J.; FALAH, M. Nature is the best source of anticancer drugs: Indexing natural products for their anticancer bioactivity. PloS one, v. 12, n. 11, p. e0187925, 2017.

RIBEIRO, V. P.; ARRUDA, C.; ABD EL-SALAM, M.; BASTOS, J. K . Brazilian medicinal plants with corroborated anti-inflammatory activities: A review.

Pharmaceutical biology, v. 56, n. 1, p. 253-268, 2018. 


\title{
Avaliação dos Polimorfismos Genéticos de Genes Relacionados ao Tabaco e a Susceptibilidade ao Desenvolvimento do Câncer
}

\author{
${ }^{1}$ Geovana Ferraz de Souza; ${ }^{1}$ Fernando Mesquita de Sousa de Lima; ${ }^{1}$ Paulo Roberto \\ Carneiro Gomes; ${ }^{1}$ Francisco Alex da Rocha Coelho; ${ }^{1}$ Rubens Renato de Sousa Carmo; \\ ${ }^{2}$ Even Herlany Pereira Alves.
}

${ }^{1}$ Graduando(a) em Biomedicina na Universidade Federal do Piauí - UFPI; ${ }^{2}$ Biomédica, pós-graduanda em Biotecnologia pela Universidade Federal do Piauí - UFPI.

\section{RESUMO}

INTRODUÇÃO: O tabagismo é hoje uma das principais práticas relacionadas ao câncer. Isso ocorre devido à metabolização da nicotina que é realizada por meio de enzimas específicas, que muitas vezes podem apresentar polimorfismos nos genes responsáveis pela sua tradução. OBJETIVO: Avaliar por meio de uma revisão literária a associação entre polimorfismos de genes relacionados ao tabagismo e a susceptibilidade ao desenvolvimento do câncer. METODOLOGIA: Trata-se de uma pesquisa de cunho bibliográfico, realizada por buscas nos bancos de dados: Scielo, Lilacs e PubMed, utilizando os seguintes descritores: Genetic Polymorphism,Tobacco e Cancer. Critérios de inclusão: artigos em inglês publicados no período de Janeiro de 2017 a Janeiro de 2019 referentes ao tema em questão. Critérios de exclusão: trabalhos que ultrapassaram o período estabelecido e que não se enquadrassem no tema. RESULTADOS E DISCUSSÃO: Foram encontrados 15 artigos, onde se utilizando do caráter de exclusão restaram apenas 8 artigos. Os resultados encontrados nos relatos permitem destacar a respeito do polimorfismo no gene $\mathrm{CYP} 2 \mathrm{~A}$, evidenciando variações genéticas como CYP2A6, CYP2A7 e CYP2A13 e um pseudogene CYP2A18. Desta forma, o estudo demonstra que o CYP2A6 está relacionado ao metabolismo da nicotina e que a variação nesse gene pode afetar o comportamento de fumantes e contribuir para o risco de câncer de pulmão. Também foi observado que o risco reduzido de câncer de pulmão em fumantes com menor atividade do CYP2A6 pode ser explicado pelo menor consumo de cigarros, tabagismo menos intenso e redução da ativação catalisada pelo CYP2A6 do carcinogênico pulmonar NNK específico para tabaco e que o gene CYP2A13 também atua relacionado ao metabolismo da nicotina, sendo que quando relacionado ao NNK pode estar relacionado ao câncer de pulmão e no NNN relacionado ao câncer de Esôfago. No que se refereao gene CYP2A7, não foi encontrada atividade catalítica para a metabolização da nicotina. Além desses genes, outros estudos também relataram polimorfismo nos genes CYP2D6 e CYP1A1 relacionados ao câncer de pulmão. CONCLUSÃO: O presente trabalho demonstrou que apesar de genes relacionados ao tabagismo possuírem polimorfismos (principalmente no gene CYP2A), os mesmos contribuem de certa forma para a susceptibilidade na formação de câncer, pois o resultado da expressão dos diferentes genes contribui para a metabolização da nicotina por meio de enzimas específicas. Mesmo com esses achados, faz-se necessário a realização de mais estudos para melhor compreensão a respeito dessa relação.

Palavras-chave: Tabagismo; Polimorfismo Genético; Câncer.

\section{Referências}

ROSSINI, A. et al. CYP2A6 polymorphisms and risk for tobacco-related cancers. 2008. 
YUAN, J. et al. Genetic determinants of cytochrome P450 2 A6 activity and biomarkers of tobacco smoke exposure in relation to risk of lung cancer development in the $S$ hanghai cohort study. International journal of cancer, v. 138 , n. 9, p. 2161-2171, 2016.

YUAN, J.-M. et al. CYP2A6 genetic polymorphisms and biomarkers of tobacco smoke constituents in relation to risk of lung cancer in the Singapore Chinese Health Study. Carcinogenesis, v. 38 , n. 4, p. $411-418,2017$. 


\title{
Bioensaio com Artemia salina (Leach) para a Detecção da Toxicidade do Extrato Etanólico da Casca de Sterculia striata a. St. Hil. \& Naudin
}

\author{
${ }^{1}$ Glíssia Lysandra dos Santos Marciel; ${ }^{1}$ Marcos Vinícius Cosme; ${ }^{1}$ Junaiza Rodrigues \\ Lima ${ }^{2}$ João Sammy Nery Souza ${ }^{3}$ Aldeídia Pereira de Oliveira ${ }^{4}$ Elisangela Claudia \\ Alves de Oliveira.
}

${ }^{1}$ Graduando (a) em Ciências Biológicas na Universidade Federal do Piauí - UFPI (Floriano); ${ }^{2}$ Professor Associado do Departamento de Química (CCN) da Universidade

Federal do Piauí - UFPI (Teresina); ${ }^{3}$ Professora Associada do Departamento de Biofísica e Fisiologia (CCS) da Universidade Federal do Piauí- UFPI (Teresina); ${ }^{4}$ Professora Adjunta do Curso de Ciências Biológicas da Universidade Federal do Piauí - UFPI (Floriano).

\section{RESUMO}

INTRODUÇÃO: A espécie Sterculia striata A. St. Hil.\& Naudin, também conhecida como chichá, pertence à família Malvaceae e está distribuída em quase todo o mundo, predominantemente nas regiões tropicais. Na medicina popular, suas folhas têm sido empregadas para o uso tópico para o tratamento da furunculose. Entretanto, apesar de suas propriedades medicinais, ainda são desconhecidos os possíveis efeitos tóxicos associados ao seu uso. Entre os testes de toxicidade utilizados atualmente, destaca-se o bioensaio com Artemia salina (Leach). Tal organismo filtrador é usado como alvo para detectar a toxicidade de compostos bioativos de extratos vegetais. A letalidade desse organismo tem sido utilizada para identificação de respostas biológicas rápidas, como a morte ou sobrevivência. OBJETIVO: O presente trabalho teve como objetivo avaliar a possível toxicidade do extrato etanólico da casca de Sterculia striata A. St. Hil.\& Naudin através do teste Artemia salina (Leach). METODOLOGIA: Inicialmente os cistos de Artemia salina foram colocados para eclodir em uma solução de 1L de água destilada para $36 \mathrm{~g}$ de $\mathrm{NaCl}$ sob iluminação e aeração constante, durante 48 horas. Posteriormente, os náuplios eclodidos foram separados com pipetas Pasteur e 10 larvas de $A$. salina foram transferidas para tubos de ensaio com concentrações que variavam de $81 \mu \mathrm{g} / \mathrm{ml}$ a 1000 $\mu \mathrm{g} / \mathrm{ml}$ do extrato etanólico da casca de Sterculia striata A. St. Hil.\& Naudin. Durante a etapa de tratamento, os tubos com as Artemias Salina foram mantidos em temperatura ambiente e sob presença constante de luz, durante 24 horas. Todos os testes foram comparados ao controle negativo. Após esse período, procedeu-se a contagem do número de organismos vivos e com mobilidade inalterada e posteriormente, foi feito um cálculo indicando o percentual de mortalidade desses organismos. A análise estatística foi realizada com o teste $t$ student e análise de variância (ANOVA) com valores de $p \leq 0,05$. RESULTADO E DISCUSSÃO: Os resultados demonstraram um declínio na taxa de sobrevivência superior a $30 \%$ para as concentrações de $500 \mu \mathrm{g} / \mathrm{ml}, 750 \mu \mathrm{g} / \mathrm{ml}$ e 1000 $\mu \mathrm{g} / \mathrm{ml}$. O aumento da mortalidade desses indivíduos pode ser devido a alterações importantes no seu genoma e/ou à sua membrana plasmática. CONCLUSÃO: Diante dos resultados obtidos, pode-se concluir que o extrato etanólico da casca de Sterculia striata A. St. Hil.\& Naudin foi tóxico neste bioensaio, quando em altas concentrações. Entretanto, outros testes também serão realizados a fim de confirmar a toxicidade do extrato etanólico da casca de Sterculia striata A. St. Hil.\& Naudin em nível celular e genético.

Palavras-chave: Toxicidade. Chichá. Artemia Salina. 


\section{Referências}

AGRA, M. F.; FREITAS, P. F.; BARBOSA-FILHO, J. M. 2007. Synopsis of the plants known as medicinal and poisonous in Northeast of Brazil. Revista Brasileira de Farmacognosia, 17: 114-140.

HEYWOOD, V. H. Flowering Plants on the World, Ed. B. T. Batsford Ltda. London, 1993.

MEYER,B.N.etal.Aconvenientgeneralbioassayforactiveplantconstituents.PlantaMedi ca,v. 45,p.31-34,1982. 


\title{
Caracterização e Correlação do Omeprazol no Processo de Morte Celular - Uma Revisão Sistemática
}

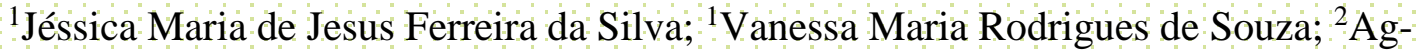 \\ Anne Pereira Melo de Menezes; ${ }^{2}$ Ana Maria Oliveira Ferreira da Mata; ${ }^{3}$ Ana Amélia de \\ Carvalho Melo Cavalcante. \\ ${ }^{1}$ Graduando (a) em Biomedicina na Universidade Federal do Piauí - UFPI; ${ }^{2}$ Pós- \\ graduada em Ciências Farmacêuticas na Universidade Federal do Piauí - UFPI; \\ ${ }^{3}$ Professora do programa de pós-graduação em ciências farmacêuticas Universidade \\ Federal do Piauí - UFPI.
}

\section{RESUMO}

INTRODUÇÃO: As lesões gástricas são caracterizadas por danos na mucosa gástrica ocasionados pela presença de infiltrado inflamatório, distúrbio endotelial e danificação da membrana celular, sendo esta última causada por espécies reativas de oxigênio. A terapêutica de escolha para essas lesões são fármacos inibidores da bomba de prótons (omeprazol), que atuam bloqueando a secreção ácida basal. No entanto, tais medicamentos encontram-se relacionados a efeitos tóxicos, os quais são responsáveis por variações genéticas, morte celular ou até mesmo carcinogênese. OBJETIVO: Diante do exposto, o presente estudo possui como objetivo caracterizar e correlacionar as atividades farmacológicas do omeprazol, bem como, seus mecanismos de proteção e indução de morte celular em estudos clínicos e não clínicos por meio e uma revisão sistemática. METODOLOGIA: Trata-se de uma revisão sistemática de caráter qualitativo e exploratório a partir de publicações indexadas em bases de dados como PubMed, Science Direct, Cochrane Library e Scielo. Como critérios de inclusão, foram analisados os estudos publicados entre os anos de 2010 e 2017, que fossem pertinentes ao tema e disponíveis nos idiomas inglês e português. E como de exclusão, artigos duplicados, ausência de descritores no título e no resumo e artigos que fogem do tema do estudo. RESULTADOS E DISCUSSÃO: Foram selecionados 144 artigos com base nos critérios de inclusão e exclusão aplicados. Observou-se que o omeprazol possui a capacidade de prevenir a morte celular em modelos de indução de lesão gástrica e intestinal, por meio da recuperação das defesas antioxidantes, modulação do processo inflamatório, diminuição de proteínas apoptóticas e aumento de marcadores antiapoptóticos. A partir da redução de áreas necróticas na mucosa gástrica, foi possível evidenciar também o seu efeito gastroprotetor, que é conhecido pela sua capacidade de impedir a bomba de prótons nas células parietais do estômago. No entanto, esta atividade dispõe de outras vias de gastroproteção, como a ativação da proteína de choque térmico (HSP70) e o fator de transformação do crescimento beta (TGF- $\beta$ ). CONCLUSÃO: Em virtude dos fatos, foi possível caracterizar e correlacionar o omeprazol como sendo um eficiente gastroprotetor capaz prevenir os danos na mucosa gástrica, reduzindo os processos indutores da morte celular. Entretanto, o medicamento demostrou atividade apoptótica em modelos xenográficos, com diminuição da massa tumoral e da viabilidade celular em linhagens cancerígenas e normais

\section{Palavras-chave: Inibidores da bomba prótons; Omeprazol; Morte Celular.}




\section{Referências}

ABDULLA, M.A.; ALI, H.M.; AHMED, K.A.; NOOR, S.M; ISMAIL, S. Evaluation of the anti-ulcer activities of Morus alba extracts in experimen-tally-induced gastric ulcer in rats. Biomedical Research, v. 20, n. 1, 2009.

ALMASAUDI, S. B.; EL-SHITANY, N. A.; ABBAS, A. T.; ABDEL-DAYEM, U. A.; ALI, S. S.; AL JAOUNI, S. K.; HARAKEH, S. Antioxidant, anti-inflammatory, and antiulcer potential of manuka honey against gastric ulcer in rats. Oxidative Medicine and Cellular Longevity, v. 2016, 2015.

BALLA, A.; TOTH, B.; TIMAR, G.; BAK, J.; KRAJCSI, P. Molecular targets for pharmacological cytoprotection. Biochem Pharmacol 61:769-777,2001.

BLANDIZZI, C.; GHERARDI, G.; MARVEGGIO, C.; NATALE, G.; CARIGNANI, D.; DEL TACCA, M. Mechanisms of protection by omeprazole against experimental gastric mucosal damage in rats. Digestion, v. 56, n. 3, p. 220-229, 1995.

BLANDIZZI, C.; NATALE, G.; GHERARDI, G.; LAZZERI, G.; MARVEGGIO, C.; COLUCCI, R.; CARIGNANI.D.;TACCA, M. Gastroprotective effects of pantoprazole against experimental mucosal damage. Fundamental \& Clinical Pharmacology, v. 14, n. 2, p. 89-99, 2000. 


\section{O Impacto nas Redes Sociais da Atividade de uma Liga Acadêmica de Genética}

${ }^{1}$ José Humberto da Cunha; ${ }^{1}$ Bárbara Rebeca de Macedo Pinheiro; ${ }^{1}$ Paloma Maria de Sousa Araujo; ${ }^{1}$ Romério de Oliveira Lima Filho; ${ }^{2}$ France Keiko Nascimento Yoshioka;

${ }^{2}$ Renata Canalle.

${ }^{1}$ Graduando (a) em Biomedicina na Universidade Federal do Piauí - UFPI; ${ }^{2}$ Professora Associada do Curso de Biomedicina da Universidade Federal do Delta do Parnaíba UFDPar/Universidade Federal do Piauí - UFPI.

\section{RESUMO}

INTRODUÇÃO: As redes sociais têm sido altamente atuantes na vida das pessoas que requerem relações interpessoais, seja no âmbito familiar, social, profissional e escolar/acadêmico. Neste último, grupos organizacionais, como as ligas acadêmicas, vêm usufruindo de várias plataformas on line para compartilharem produções científicas, interagirem com o público e propagarem conhecimentos. OBJETIVO: Considerando que uma das atividades da Liga Acadêmica de Genética - LiAGen está voltada ao Conexão LiAGen, que visa a postagem de conteúdos de cunho científico na área da genética, o presente trabalho teve como objetivo avaliar o impacto dessa atividade em uma rede social. METODOLOGIA: No Instagram da LiAGen foram publicadas oito perguntas no período de tempo de 24 horas referentes à satisfação do público quanto às atividades do: LiAGen Blog (postagem de texto descritivo referente aos conceitos da genética); LiAGen Test (postagem de perguntas, elaboradas pelos ligantes, e disponibilizadas na ferramenta story do Instagram para que o público escolha a melhor resposta e, ao mesmo tempo, testarem seus conhecimentos); LiAGen+ (postagem de um pequeno texto com curiosidades sobre a genética); e LiAGen Science (postagem de um texto de caráter científico que relata os últimos avanços da ciência correlacionado com a genética). As respostas dessas perguntas foram restritas a SIM ou NÃO, desconsiderando a identidade e origem de cada participante. Sendo assim, conforme o que esclarece a resolução CNS 510/16, o estudo é isento da avaliação do sistema CEP/CONEP, tendo em vista que se trata de uma pesquisa de opinião pública com participantes não identificados. RESULTADOS E DISCUSSÃO: Após as 24 horas, as oito perguntas atingiram o número médio de 161 pessoas que visualizaram as questões, no entanto, para cada questão o número de amostragem foi diferente sendo a média amostral de pessoas votantes com o número aproximado de 47 respostas por pergunta. Das oito perguntas, quatro atingiram a pontuação máxima (100\%), as quais refletiram a satisfação do público quanto a facilitação do aprendizado, a relevância dos assuntos e que gostariam de continuar tendo acesso às postagens. Sobre o LiAGen Blog, foi observado que $63 \%$ do público compreendem a produção textual; o LiAGen Test tem sido a melhor atividade realizada pelo projeto Conexão LiAGen, com $88 \%$ de aceitação; $76 \%$ desconhecem atividade do LiAGen+, e $51 \%$ conhecem o propósito da atividade do LiAGen Science. CONCLUSÃO: Diante dos acessos e dos resultados obtidos, o LiaGen+ requer uma divulgação maior de seu conteúdo, mas de forma geral, as atividades do Conexão LiAGen mostraram-se relevantes, com grande abrangência e aceitação pelo público.

\section{Palavras-chave: Instagram. Genética. Ciência}




\section{Referências}

Albagli S. Divulgação científica: informação científica para a cidadania?, Brasília, 1996.

BRASIL. Ministério da Saúde. Conselho Nacional de Saúde. Resolução n ${ }^{\circ} 510$, de 7 de abril de 2016.

Caetano GCG, Matos HOS, Simão PCR. CRISPR-CAS9's Technical and its use in the Laboratory Area. Brazilian Journal of Surgery and Clinical Research. 2019.

Gonçalves GAR, Paiva RMA. Gene therapy: advances, challenges and perspectives. Hospital Israelita Albert Einstein, São Paulo. 2017.

Mukherjee S. Genetic therapies: posthuman gene therapy. Nova York Scribner. 2016. 


\section{Eliminação do Genoma Viral do HIV do Material Genético Humano pelo CRISPR-Cas9: Uma Revisão Bibliográfica}

Antônio Kleiton de Sousa ${ }^{1}$; Francisco Alex da Rocha Coelho ${ }^{1}$; Wesley Rodrigues da Silva ${ }^{1}$; Geovanna Ferraz de Souza ${ }^{1}$; Philipe Veras Pires ${ }^{1}$; Thiago Nobre Gomes ${ }^{2}$.

${ }^{1}$ Graduandos do curso de Bacharelado em Biomedicina da Universidade Federal do Piauí - UFPI; ${ }^{2}$ Professor do curso de Bacharelado em Biomedicina da Universidade Federal do Piauí - UFPI.

\section{RESUMO}

INTRODUÇÃO: Passadas mais de três décadas desde a descoberta clínica do Vírus da Imunodeficiência Humana (HIV) desde o início da sua epidemia, 32 milhões de pessoas morreram de doenças relacionadas à Síndrome da Imunodeficiência Adquirida (AIDS), e 37,9 milhões de pessoas no mundo vivem com HIV. Estudos recentes com o sistema de edição de genes a partir de repetições palindrômicas curtas inter-espaçadas regularmente agrupadas (CRISPR-Cas9) mostram-se promissores na eliminação do genoma viral do material genético humano. OBJETIVO: Analisar a literatura científica investigando o potencial de eliminação do genoma viral do HIV do material genético humano, pelo sistema CRISPR-Cas9. METODOLOGIA: Trata-se de um estudo retrospectivo, com revisão bibliográfica a partir de publicações indexadas nas bases de dados PubMed e SciELO. Utilizou-se como descritores de busca os termos "HIV e CRISPR-Cas9" tanto em inglês quanto em português. Como critérios de inclusão, considerou-se as pesquisas publicadas no recorte temporal de 2015 a 2019, disponíveis na íntegra, abordando o referido tema. RESULTADOS E DISCUSSÃO: Dos 177 artigos encontrados inicialmente, 145 foram excluídos por não atenderem os critérios selecionados, e 32 constituíram a amostra final. O sistema CRISPR-Cas9 contém uma endonuclease que detecta e cliva o genoma do HIV, e a mesma é direcionada através do RNA guia (gRNA). O alvo é o domínio de Repetição Terminal Longa (LTR) que controla a replicação e transcrição viral nas posições 5' e 3', ocorrendo clivagem nesses pontos e a ligação das extremidades, que resulta na excisão do material genético interferente. Dados experimentais in silico sugeriram que o sistema é eficaz contra cerca de $82-95 \%$ de todas as variantes do HIV-1 subtipo B. Estudos in vitro com células humanas e in vivo em ratos infectados relatam a erradicação de todo o genoma do HIV-1 por CRISPR-Cas9 em células $\mathrm{T}$ e células reservatórias, podendo-se eliminar mais de uma cópia do genoma viral de uma célula infectada, mesmo quando o vírus esteja integrado em várias regiões do genoma do hospedeiro. Além disso, o CRISPR-Cas9 pode ser usado para imunizar células contra o HIV, levando sua rápida eliminação antes mesmo da sua integração ao genoma do hospedeiro. CONCLUSÃO: O revolucionário sistema CRISPR-Cas9 mostra grande potencial para a eliminação total do HIV das células humanas, sendo uma técnica altamente versátil para lidar com a diversidade genética do HIV. Contudo, estudos mais avançados são necessários para uma compreensão mais ampla dos diferentes mecanismos moleculares envolvidos na terapia com este sistema.

\section{Palavras-chave: HIV; Edição de genes; Sistemas CRISPR-Cas.}

\section{Referências}

DAS, A. T.; BINDA, C. S.; BERKHOUT, B. Elimination of infectious HIV DNA by CRISPR-Cas9. Current opinion in virology. v. 38. p. 81-88. 2019. DOI: 0.1016/j.coviro.2019.07.001. 
HUANG, Z; TOMITAKA, A.; RAYMOND, A.; NAIR, M. Current application of CRISPR/Cas 9 gene-editing technique to eradication of HIV/AIDS. Gene therapy. v. 24. n. 7. p. $377-384$. 2017. DOI: $10.1038 /$ gt. 2017.35

PANFIL, A. R.; LONDON, J. A.; GREEN, P. L.; YODER, K. E. CRISPR/Cas9 Genome Editing to Disable the Latent HIV-1 Provirus. Frontiers in Microbiology. v.9. 2018. DOI: $10.3389 /$ fmicb.2018.03107

YIN, L.; HU, S.; MEI, S.; SUN, H.; XU, F.; LI, J.; ZHU, W.; LIU, X.; ZHAO, F.; ZHANG, D.; CEN, S.; LIANG, C.; GUO, F. CRISPR/Cas9 Inhibits Multiple Steps of HIV-1 Infection. Human gene therapy. v. 29. n. 11. p. 1264-1276. 2018. DOI: 10.1089/hum.2018.018

ZHU, W.; LEI, R.; LE DUFF, Y.; LI, J.; GUO, F.; WAINBERG, M. A.; LIANG, C. The CRISPR/Cas 9 system inactivates latente HIV-1 proviral DNA. Retrovirology. v. 27. 2015. DOI: 10.1186 / s12977-015-0150-z 


\title{
Erosão Genética em Espécies Vegetais no Brasil: Revisão de Literatura
}

\author{
${ }^{1}$ Beatriz Pereira Costa; ${ }^{1}$ Bárbara Rebeca de Macedo Pinheiro; ${ }^{1}$ Lucas Florencia da Silva; \\ ${ }^{1}$ Romério de Oliveira Lima Filho; ${ }^{2}$ Irlaine Rodrigues Vieira. \\ ${ }^{1}$ Graduandos do curso de Bacharelado em Biomedicina da Universidade Federal do \\ Piauí - UFPI; ${ }^{2}$ Bióloga da Universidade Federal do Piauí - UFPI.
}

\section{RESUMO}

INTRODUÇÃO: A diversidade biológica refere-se a variabilidade de organismos vivos de todas as origens, destacando-se a sua diversidade genética. A manutenção da diversidade é importante por diversos motivos, principalmente para a homeostase global. A ação humana vem afetando a diversidade biológica vegetal, por meio da destruição do habitat natural e substituição de variedades crioulas por variedades modificadas geneticamente. Isso vem promovendo a erosão genética pela perda de genes ou combinações gênicas. OBJETIVO: Apresentar e discutir as principais causas de erosão genética em espécies vegetais no Brasil. METODOLOGIA: Trata-se de um estudo retrospectivo, com revisão bibliográfica. A busca por publicações para a composição deste estudo foi feita através das bases de dados do SCIELO e Acesso livre à Informação Científica da Embrapa (ALICE). Por sua vez, os descritores Genetic Erosion e Plants, associados ao país Brasil, foram utilizados. Tais estudos deveriam estar disponíveis para download e nos idiomas Inglês, Português e Espanhol além de terem sido publicados entre os anos de 2010 até 2019. RESULTADOS E DISCUSSÃO: Devido a crescente ação antrópica na natureza, uma série de eventos têm ocorrido e são responsáveis pela erosão genética de muitas espécies vegetais. Estas plantas acabam sendo diretamente afetadas, o que faz com que a variabilidade genética delas fique cada vez mais limitada. Exemplos de plantas que vem sendo atingidas por esses acontecimentos são Solanum tuberosum (Batata), Maytenus ilicifolia (Espinheira-santa), Capsicum baccatum (Pimentas dedo-demoça e cambuci) e Plinia cauliflora (Jaboticaba). As principais causas de erosão gênica no Brasil, descritas na literatura, são a elevação de temperatura nos centros de origem, que leva a perdas de espécies silvestres de grande importância ao melhoramento genético; a devastação florestal para cultivos, que causa a perda de populações que são fontes de genes para tolerância ou resistência aos estresses bióticos e abióticos; a exploração exacerbada de plantas sem critérios de manejo adequado, ocasionando a redução demográfica drástica das mesmas, bem como perda significativa de diversidade genética e provocaram um fluxo gênico entre espécies. CONCLUSÃO: Nessa perspectiva, observa-se que, no Brasil, as principais causas de erosão genética são a elevação da temperatura, a substituição de cultivos, a exploração de plantas nativas e ações antrópicas. Esses acontecimentos são comuns e devem ser mitigados para que a preservação dos genes tradicionais da flora brasileira seja zelada e posteriores problemas no meio ambiente sejam evitados.

Palavras-chave: Erosão Antrópica; Plantas; Variação Genética.

\section{Referências}

CARVALHO, J. M. F. C.; SILVA, M. M. A.; MEDEIROS, M. J. L. Perda e conservação dos recursos genéticos vegetais. Embrapa Algodão-Documentos. Campina Grande. 2009. 19p. 
JÚNIOR, A. W. et al. Genetic divergence of native jaboticaba fruit tree (Plinia cauliflora) based on fruit quality. Semina: Ciências Agrárias, v. 39, n. 6, p. 2409-2424, 2018.

LOPES, C. A. et al. An analysis of the potato production in Brazil upon global warming. Horticultura Brasileira, v. 29, n. 1, p. 7-15, 2011.

RIBEIRO, M. V. et al. Genetic diversity of" espinheira-santa"(Maytenus ilicifolia Mart. ex Reis.) accessions collected in Rio Grande do Sul State, Brazil. Revista Brasileira de Plantas Medicinais, v. 12, n. 4, p. 443-451, 2010.

VILLELA, J. C. B. et al. Molecular characterization of landraces of peppers (Capsicum baccatum) with SSR markers. Horticultura Brasileira, v. 32, n. 2, p. 131-137, 2014. 


\section{Farmacogenética da Esquizofrenia: Uma Revisão da Literatura}

${ }^{1}$ Geovanna Ferraz de Souza; ${ }^{1}$ Francisco Alex da Rocha Coelho; ${ }^{1}$ Antônio Kleiton de Sousa; ${ }^{1}$ Ângela Vitória Vieira Pereira; ${ }^{1}$ Fernando Mesquita de Sousa de Lima; ${ }^{2}$ Even Herlany Pereira Alves.

${ }^{1}$ Graduando (a) em Biomedicina na Universidade Federal do Piauí - UFPI; ${ }^{2}$ Biomédica, pós-graduanda em Biotecnologia pela Universidade Federal do Piauí - UFPI.

\section{RESUMO}

INTRODUÇÃO: A esquizofrenia e os denominados transtornos esquizofrênicos constituem um grupo de distúrbios mentais graves, altamente complexos, de caráter multifatorial, sem sintomas específicos. Embora a maioria dos pacientes com tal transtorno responda adequadamente às terapias com antipsicóticos, boa parte mostra respostas não adequadas podendo estar associados a genes que podem potencialmente influenciar o tratamento. OBJETIVOS: Avaliar como as variantes genéticas interindividuais 'podem influenciar na resposta antipsicótica contra a esquizofrenia. METODOLOGIA: Trata-se de uma revisão literária a partir de publicações indexadas nas bases de dados SciELO, PubMed e Lilacs. Utilizou-se como descritores de busca os termos "farmacogenética", "esquizofrenia" e "terapia" de forma isolada e associada, utilizando-se de operadores booleano entre os termos, tanto em inglês quanto em português. Como critérios de inclusão, considerou-se as pesquisas publicadas no recorte temporal de 2014 a 2019, disponíveis na íntegra e que abordam a referida temática. Foram excluídas as publicações que destoavam desses critérios e os trabalhos duplicados. RESULTADOS E DISCUSSÃO: Ao todo, foram encontrados nos três bancos de dados 64 artigos, sendo 15 duplicados e 27 que não possuíam ligação direta com o tema, selecionando-se, assim, 22 publicações para a confecção da revisão. Em alguns casos, como na esquizofrenia, a heterogeneidade da reposta não pode ser associada somente a fatores fisiológicos e ambientais, como também a fatores genéticos como uma possível fonte de variação frente à terapêutica. A população que se classifica como metabolizadores pobres ou lentos (PMs) tem deficiência na capacidade metabólica quando comparada a indivíduos com metabolismo normal, podendo sofrer reações adversas no tratamento com um fármaco, assim como os que possuem um metabolismo ultrarrápido (UMs), pois o catabolismo dos fármacos é muito alto, havendo a necessidade de doses mais fortes. Em outro estudo, observou-se que a família de enzimas CYP, com destaque para as proteínas CYP2D6, CYP1A2, CYP3A5, CYP2C9 e CYP2C19, possui grande influência na metabolização de medicamentos psicotrópicos. Foi observado que o gene CYP3A5 apresenta grande número de variantes alélicos, dentre as variantes encontra-se 6986>G que promove uma atividade severamente reduzida à enzima. CONCLUSÃO: Juntando os fatores externos com os polimorfismos dos genes que estão relacionados à esquizofrenia, a refratariedade ao tratamento psiquiátrico é induzida. Assim, a resposta clínica dos pacientes tratados com antipsicóticos é muito variável, sendo ainda o principal problema no manuseio do transtorno esquizofrênico. Ainda faltam estudos relacionados à esquizofrenia e seus diversos mecanismos, o que pode estar relacionado à sua falta de marcadores biológicos e sua diversidade fenotípica.

Palavras-chave: Polimorfismo; Farmacologia; Transtornos esquizofrênicos. 


\section{Referências}

DROGEMÖLLER, B. I. et al. Patterns of variation influencing antipsychotic treatment outcomes in South African first-episode schizophrenia patients. Pharmacogenomics, v. 15, n. 2, p. 189-199, 2014.

POUGET, J. G. et al. Pharmacogenetics and outcome with antipsychotic drugs. Dialogues in clinical neuroscience, v. 16, n. 4, p. 555, 2014.

YE, J. et al. Polymorphisms in Dopaminergic Genes in Schizophrenia and Their Implications in Motor Deficits and Antipsychotic Treatment. Frontiers in neuroscience, v. 13, 2019. 


\section{Gene P63 e o Controle de Qualidade de Gametas Femininos}

1Dandara Maria Silva Araújo; ${ }^{1}$ Maria de Jesus Pereira Gomes; ${ }^{2}$ Jéssica Maria de Jesus Ferreira da Silva; ${ }^{2}$ Gustavo Oliveira Monteiro Alves; ${ }^{3}$ Luciana Rocha Faustino.

${ }^{1}$ Graduanda em Licenciatura em Ciências Biológicas na Universidade Federal do Piauí UFPI; ${ }^{2}$ Graduando (a) em Biomedicina na Universidade Federal do Piauí - UFPI;

${ }^{3}$ Professora Adjunta em Medicina na Universidade Federal do Piauí - UFPI.

\section{RESUMO}

INTRODUÇÃO: O gene p63 pertence à família p53, reguladora chave do ciclo celular, e pode ser codificado em seis isoformas. Dentre suas isoformas, a TAp63 tem sido considerada a guardiã da integridade da linhagem germinativa feminina devido sua atividade próapoptótica no oócito. Sendo assim, esse gene desponta como um alvo promissor para estudos que visam a preservação da função ovariana após tratamentos oncológicos. OBJETIVO: Levantar resultados de estudos relacionados ao gene p63 e seu controle de qualidade em oócitos, visando a preservação de oócitos após utilização de tratamentos contra o câncer. METODOLOGIA: Foram analisados 16 artigos levantados da fonte de dados PubMed, que correlacionaram as atuações do $p 63$ e suas isoformas no controle de qualidade de oócitos in vivo e in vitro, no período de 2006 a 2019. As buscas foram realizadas através dos termos: "p63 gene", "TAp63", "Infertility", "Oocyte" e suas combinações. RESULTADOS E DISCUSSÃO: De modo geral, as análises mostraram que o p63 foi o único membro da família p53 expresso no núcleo oócitário. A expressão da isoforma TAp63 $\alpha$ foi observada em abundância em oócitos de diferentes estágios do desenvolvimento folicular, sugerindo que está envolvida no controle da meiose e do ciclo celular de gametas femininos. Estudos recentes mostraram que a TAp63 regula a propensão de oócitos a sofrerem apoptose e monitora os danos no DNA em um ponto de verificação, eliminando oócitos que sofreram danos no DNA. Foi evidenciado ainda que a depleção induzida por irradiação do pool de folículos quiescentes (folículos primordiais) resulta da ativação de $p 63$ em oócitos quiescentes. Dessa maneira, os trabalhos sugerem que a supressão da TAp63 $\alpha$ poderia contribuir para preservação de oócitos. Porém, existe uma preocupação sobre os níveis de mutações em oócitos sobreviventes após supressão da atividade da proteína. Em adição, ainda não está claro se a atividade pró-apoptótica de TAp63a no oócito atua como gatilho principal na manutenção da integridade do gameta feminino. CONCLUSÃO: O levantamento dos estudos mostra que TAp63 $\alpha$ é expressa especificamente em oócitos, regulando ponto de verificação no ciclo celular e a propensão dessas células a sofrerem apoptose, de forma que a morte de oócitos após danos no DNA requer $p 63$. Informações sobre os mecanismos de resistência que envolvem danos no DNA e o gene p63 em oócitos podem ajudar a prevenir a infertilidade, especialmente em mulheres que precisam de tratamentos oncológicos.

\section{Palavras-chave: Oócito; DNA; Quimioterapia; Fertilidade.}

\section{Referências}

AMELIO, I. et al. p63 the guardian of human reproduction. Cell Cycle, v. 11, n. 24, p. 4545-4551, jun. 2012. 
COUTANDIN, D. et al. Quality control in oocytes by p63 is based on a spring-loaded activation mechanism on the molecular and cellular level. eLife, p. online 1-22, mar. 2016.

DEUTSCH, G. B. et al. DNA damage in oocytes induces a switch of the quality control factor TAp63 $\alpha$ from dimer to tetramer. Cell, v. 144, p. 566-576, 2011.

GONFLONI S, et al. Inhibition of the c-Abl-TAp63 pathway protects mouse oocytes from chemotherapy-induced death. Nat Med, v. 15, n. 10, p. 1179-1185, 2009.

RINALDI, V. Pharmacological Inhibition of the DNA Damage Checkpoint Prevents Radiation-Induced Oocyte Death. Genetics, v. 206, n. 4, p.1823-1828, aug. 2017. 


\title{
Importância do Diagnóstico das Hemoglobinopatias em Gestantes
}

\author{
${ }^{1}$ Maria Rikelly Frota Aguiar; ${ }^{1}$ Daniele Alcoforado Costa; ${ }^{1}$ Sandiely Santos da Silva; \\ ${ }_{1}^{1}$ Joana Darc Viana Silva; ${ }^{2}$ Josiane da Silva Costa; ${ }^{3}$ Antonia Luzia Lima do Nascimento. \\ ${ }^{1}$ Graduando (a) em Biomedicina na Universidade Federal do Piauí - UFPI; ${ }^{2}$ Graduando \\ (a) em Biologia na Universidade Federal do Piauí - UFPI; ${ }^{3}$ Biomédica pela \\ Universidade Federal do Piauí - UFPI.
}

\begin{abstract}
RESUMO
INTRODUÇÃO: As hemoglobinopatias são alterações na hemoglobina que acontece de forma hereditária, sendo as mais comuns no Brasil a anemia falciforme, a hemoglobina $\mathrm{C}$ e talassemias alfa e beta. Gestantes que apresentam o genótipo (SS, SC ou S-ß3Talassemia), podem gerar prejuízos tanto para a mulher quanto para o recém-nascido, pois a gestação é um fator que pode agravar o nível da doença e consequentemente o desenvolvimento da mesma. Com exames de pré-natal e aconselhamento genético em gestantes ou em mulheres que buscam engravidar pode ser feito assim o controle das hemoglobinopatias. Isso reforça a ideia da importância da realização de exames adequados para poder prosseguir com uma gestação. OBJETIVO: Mostrar a importância da implantação e do cuidado ao se tratar de casais que tenham riscos de possuírem tais genótipos que são característicos das hemoglobinopatias com relação ao desenvolvimento de uma gestação. METODOLOGIA: Foram avaliados artigos indexados nas bases de dados Scielo e Pubmed tanto no idioma português como inglês, utilizando os descritores de buscas "hemoglobinopatias", "doenças hereditárias" e "gestação" para assim entender a importância de um aconselhamento em descobrir tais condições genéticas também no pré-natal. RESULTADOS E DISCUSSÃO: Na pesquisa foi percebido que há uma elevada prevalência de hemoglobinopatias em gestantes, tornando assim o diagnóstico precoce e o aconselhamento genético de grande importância durante este período. Há uma relação de casos de condições com hemoglobinas anormais com a questão racial e também fatores ambientais dependendo da região analisada. Com a pesquisa, foi visto que a introdução do exame preventivo para patologias genéticas para grávidas não é algo complicado, pois tais já possuem uma rotina de exames para acompanhamento da gravidez devido à preocupação da mãe com a saúde do bebê, deve-se entender que quanto mais precoce o diagnóstico do paciente melhor o tratamento, principalmente em casos de homozigose. $\mathrm{O}$ acompanhamento médico será iniciado de forma rápida e adequada, assim o recém-nascido terá melhores condições de vida. É preciso ressaltar que as mulheres apresentam muitas complicações durante o período gestacional como na anemia falciforme. CONCLUSÃO: A realização dos exames de pré-natal e o aconselhamento genético irão proporcionar tanto a melhor sobrevida do bebê e melhores chances para a mãe, e o aconselhamento genético pode evitar o nascimento de portadores das hemoglobinopatias. Por isso que a compreensão sobre os benefícios que estes cuidados podem trazer principalmente as que são hereditárias, apresentam grande valia quando há uma monitoração gestacional para uma gravidez saudável.
\end{abstract}

Palavras-chave: Hemoglobinopatias; Gestantes; Genética.

\section{Referências}

BARBOSA, Ana Maria Rodrigues et al. PREVALÊNCIA DE HEMOGLOBINOPATIAS EM GESTANTES ASSISTIDAS POR UM LABORATÓRIO DE SAÚDE PÚBLICA NO PIAUÍ. Jornal de Ciências da Saúde do 
Hospital Universitário da Universidade Federal do Piauí, [s.1.], v. 1, n. 2, p.73-84, 13 ago. 2018. Universidade Federal do Piaui.

http://dx.doi.org/10.26694/25950290.20181273-847140.

LIBERATO, Keesi Marcela Matos; OSELAME, Gleidson Brandão; NEVES, Eduardo Borba. Hemoglobinopatias em gestantes submetidas ao teste da mãezinha na rede pública de saúde. Revista Brasileira Ciências da Saúde - Uscs, [s.1.], v. 15, n. 51, p.46-51, 27 abr. 2017. USCS Universidade Municipal de Sao Caetano do Sul. http://dx.doi.org/10.13037/ras.vol15n51.4266.

OSENFELD, Luiz Gastão et al. Prevalência de hemoglobinopatias na população adulta brasileira: Pesquisa Nacional de Saúde 2014-2015. Revista Brasileira de

Epidemiologia, [s.1.], v. 22, n. 2, p.19, 2019. FapUNIFESP (SciELO).

http://dx.doi.org/10.1590/1980-549720190007.supl.2. 


\section{"Jogo da Memória: Que Herança é essa?" Como Instrumento Facilitador no Ensino de Genética}

${ }^{1}$ Marilha Vieira de Brito; ${ }^{2}$ Junielson Soares da Silva; ${ }^{3}$ Ana Paula da Silva Costa; Franciele de Sousa Santos; ${ }^{2}$ Dayane Vieira Lima; Gérson do Nascimento Costa ${ }^{1}$.

${ }^{1}$ Mestre em Genética e Melhoramento (PPGM) na Universidade Federal do Piauí UFPI; ${ }^{2}$ Mestre em Genética, Conservação e Biologia Evolutiva, no Instituto Nacional de Pesquisas da Amazônia e Professor da Seduc-PI; ${ }^{3}$ Graduada em Licenciatura em Ciências Biológicas na Universidade Estadual do Maranhão-UEMA.

\section{RESUMO}

INTRODUÇÃO: Os conteúdos de Genética muitas vezes são ditos pelos alunos como difíceis de aprender, seja por ser um ramo da biologia que estes alunos aleguem ter muitos cálculos, ou complexidade dos conceitos, neste caso trata-se de um ramo da biologia, que necessita de atividades que visem facilitar o aprendizado e assim modificar a visão que muitos desses alunos têm dessa área da biologia como "chata" e "difícil de aprender. A prática de atividades que ajudem a esclarecer muitos dos assuntos em Genética tem sido uma preocupação constante de muitos professores de biologia. Atualmente, os jogos didáticos têm ocupado cada vez mais espaço no campo educacional. OBJETIVO: Desenvolver de um jogo didático como forma de facilitar a aprendizagem quanto a conceitos importantes relacionados a herança genética. METODOLOGIA: o presente trabalho teve como público-alvo amostragem de 289 estudantes de ensino médio pertencentes a 03 (três) escolas, sendo 2 (duas) públicas estaduais situadas no município de Coelho Neto-MA; e uma particular, situado no município de Buriti-MA (os grupos foram caracterizados como $\mathrm{A}, \mathrm{B}$ e $\mathrm{C}$ respectivamente). Foi aplicado um questionário antes e após a explanação do jogo, afim de observar a eficiência do mesmo frente a obtenção de conteúdos relacionados herança genética. O jogo em questão possui 16 cartas, sendo que uma carta contém a definição da herança e seu respectivo par apresenta uma imagem e o nome da herança genética como mostra a figura a seguir. O aluno deverá montar o par de cartas de acordo com as principais heranças genéticas estudadas em Biologia no Ensino Médio. RESULTADOS E DISCUSSÃO: Durante a aplicação do jogo didático verificou-se que o mesmo possibilitou à socialização, a comunicação, a construção do conhecimento e também despertou o interesse dos alunos sobre os conteúdos de genética. Esses fatores provavelmente estão ligados a progressão quanto acertos, quando comparados pré e pós-teste. Os resultados deste estudo mostraram que a turma "A", no pré-teste, obteve $43 \%$ de acertos e após a aplicação do jogo, somou $53 \%$ no pós-teste. A turma "B", no pré-teste, teve um percentual de $57 \%$ de acertos nas questões, enquanto que no pós-teste os mesmos alunos apresentaram um percentual de acertos de $80 \%$. A turma "C" alcançou 65\% de acertos no pré-teste e após a utilização do jogo como proposta complementar, esse índice aumentou para $77 \%$ no pós-teste. CONCLUSÃO: Com a aplicação dos pré-testes e pós-testes, constatou-se um aumento nos índices percentuais de acertos após o uso do jogo didático. Estes resultados permitiram confirmar que a atividade lúdica realizada favoreceu a construção de uma aprendizagem significativa.

\section{Palavras-chave: Aprendizagem; Herança Genética; Jogo Didático.}




\section{Referências}

GOMES, R.R.; FRIEDRICH, M.A. (2001). Contribuição dos jogos didáticos na aprendizagem de conteúdos de Ciências e Biologia. In: EREBIO,1, Rio de Janeiro, 2001, Anais..., Rio de Janeiro, p.389-392.

COSTA, G. N. ; PEIXOTO, L. R. Padrões de Herança Biológica em Jogo. In: Mostra de Ciência e Tecnologia das Entidades Estudantis (UBES, UNE, ANPG), Pernambuco, 2013, Anais..., Pernambuco, p. 53-56.

PAES, M. F.; PARESQUE, R. Jogo da Memória: Onde está o gene? Revista Genética na Escola. Rio de Janeiro, v.9 n.1 p. 29-26, 2009.

RIEDER, R.; ZANELATO, E.M.; BRANCHER, J.D. Observação e análise da aplicação de jogos educacionais bidimensionais em um ambiente aberto. IX TALLER INTERNACIONAL DE SOFTWARE EDUCATIVO São Paulo 2004, Anais... Rio de Janeiro, 2004. P. 61-66.

ZANON, D.A.V.; GUERREIRO, M.A.S.; OLIVEIRA; R.C. (2008). Jogo didático Ludo Químico para o ensino de nomenclatura dos compostos orgânicos: projeto, produção, aplicação e avaliação. Revista Ciências e Cognição, 13:72-81. 


\title{
Diagnóstico de Infecções por Clostridioides difficile a partir da Técnica de PCR Quantitativa: Uma Revisão Bibliográfica
}

${ }^{1}$ Lucas Florencia da Silva; ${ }^{1}$ Rodrigo Elísio de Sá; ${ }^{1}$ Brenda Nascimento Dias; ${ }^{1}$ Naira Celeste da Costa Ferreira; ${ }^{1}$ Airton Lucas Sousa dos Santos; ${ }^{2}$ Thiago Nobre Gomes.

${ }^{1}$ Discente do curso de bacharelado em Biomedicina da Universidade Federal do Piauí UFPI; ${ }^{2}$ Docente do curso de bacharelado em Biomedicina da Universidade Federal do Piauí - UFPI.

\begin{abstract}
RESUMO
INTRODUÇÃO: A PCR quantitativa (qPCR) é um método estabelecido para a detecção, quantificação e tipagem de diferentes microrganismos. Infecções por Clostridioides difficile (ICD) são frequentemente encontradas na prática clínica, sendo as bactérias anaeróbias gram-positivas mais prevalentes nos Estados Unidos. Hodiernamente, a incidência e a gravidade da ICD aumentam acentuadamente no mundo. Tais bactérias são formadoras de esporos e produtoras de toxinas que causam inflamação e diarreia, e estas manifestações da infecção podem evoluir para colite pseudomembranosa, sepse e óbito. Recentemente, pesquisadores sugeriram que o método de qPCR é o mais sensível e preciso para o diagnóstico da ICD. Isto implica no refreio de exames repetidos do teste de toxinas por ensaios imunoenzimáticos ou da cultura de toxinas, reduzindo a duração da internação e o ônus econômico. OBJETIVO: Averiguar a eficácia do uso da metodologia de qPCR no diagnóstico da ICD, com base na literatura recente. METODOLOGIA: Trata-se de um estudo retrospectivo, com revisão bibliográfica a partir da busca por publicações indexadas nas bases de dados EMBASE, PubMed e SCOPUS, disponíveis para download, redigidas em Inglês e publicadas no recorte temporal de 2015 até 2019, auxiliado pelo Protocolo PRISMA (Preferred Reporting Items for Systematic Reviews and Meta-Analyses). RESULTADOS E DISCUSSÃO: Os principais determinantes da virulência em $C$. difficile são as toxinas $\mathrm{A}$ e $\mathrm{B}$, dois membros da grande família de citotoxinas clostridiais que são codificadas pelos genes $t c d A$ e $t c d B$, respectivamente. Ambos estão localizados em uma região de 19,6 kb do cromossomo bacteriano conhecida como locus de patogenicidade. Diante da leitura e análise dos 14 artigos constituintes da amostra final, 92,8\% $(n=13)$ destes demonstraram que a metodologia de qPCR frente ao diagnóstico de ICD exerce taxas mais satisfatórias nos parâmetros de especificidade, sensibilidade e tempo de resultado em relação às metodologias convencionais (como ensaios imunoenzimáticos e cultura toxigênica). Ademais, $71,4 \%$ dos artigos $(n=10)$ ressaltam que somente a dependência exclusiva de testes moleculares para o diagnóstico de ICD, sem a realização dos testes de toxinas ou resposta do hospedeiro, provavelmente resultará em diagnóstico equivocado, tratamento excessivo e aumento dos custos para os serviços de saúde. CONCLUSÃO: Desta forma, fica evidente que o manejo adequado da ICD requer compreensão sobre os vários métodos de diagnóstico e opções terapêuticas, além de medidas para prevenção da mesma. Ademais, a metodologia de qPCR é uma via inescusável e altamente relevante devido aos resultados precisos que ela confere frente ao diagnóstico desta infecção.
\end{abstract}

Palavras-chave: Clostridium difficile; Diagnóstico; Reação em Cadeia da Polimerase em Tempo Real. 


\section{Referências}

GUH, Alice Y.; KUTTY, Preeta K.. Clostridioides difficile Infection. Annals Of Internal Medicine, [s.1.], v. 169, n. 7, p.49-63, 2 out. 2018. American College of Physicians. http://dx.doi.org/10.7326/aitc201810020.

KRALIK, Petr; RICCHI, Matteo. A Basic Guide to Real Time PCR in Microbial Diagnostics: Definitions, Parameters, and Everything. Frontiers In Microbiology, [s.1.], v. 8, p.1-9, 2 fev. 2017. Frontiers Media SA. http://dx.doi.org/10.3389/fmicb.2017.00108

POLAGE, Christopher R. et al. Overdiagnosis of Clostridium difficile Infection in the Molecular Test Era. Jama Internal Medicine, [s.1.], v. 175, n. 11, p.1792-1801, 1 nov. 2015. American Medical Association (AMA).

http://dx.doi.org/10.1001/jamainternmed.2015.4114.

PRETE, R. del; RONGA, L.; ADDATI, G.. Clostridium difficile. A review on an emerging infection. La Clinica Terapeutica, [s.1.], n. 1, p.41-47, 28 fev. 2019. Società editrice universo. http://dx.doi.org/10.7417/CT.2019.2106.

SONG, Pil Hun et al. Rapid and accurate diagnosis of Clostridium difficile infection by real-time polymerase chain reaction. Intestinal Research, [s.1.], v. 16, n. 1, p.109-115, 2018. Korean Association for the Study of Intestinal Diseases.

http://dx.doi.org/10.5217/ir.2018.16.1.109. 


\section{Hemocromatose Hereditária Juvenil a partir da Mutação do gene HAMP: uma revisão bibliográfica}

${ }^{1}$ Lucas Florencia da Silva; ${ }^{2}$ Thiago Nobre Gomes; ${ }^{1}$ Rodrigo Elísio de Sá; ${ }^{1}$ Bárbara Rebeca de Macedo Pinheiro, ${ }^{1}$ Beatriz Pereira Costa.

${ }^{1}$ Discente do curso de Bacharelado em Biomedicina da Universidade Federal do Piaú UFPI; ${ }^{2}$ Docente do curso de Bacharelado em Biomedicina da Universidade Federal do Piauí - UFPI.

\section{RESUMO}

INTRODUÇÃO: O ferro é um metal essencial para a sobrevivência celular, regulado pelo hormônio peptídico hepcidina. Este hormônio é codificado pelo gene HAMP (19q13.12), tem sua síntese a nível hepático e desempenha papel importante na regulação da homeostase sistemática do ferro. Ressalta-se que a hepcidina não apenas intervém na absorção deste metal na dieta e sua saída das células de armazenamento, mas também induz sua redistribuição em vários órgãos. A hepcidina desregulada é frequentemente vista em uma variedade de doenças relacionadas ao ferro, em especial no caso de distúrbios de sobrecarga deste elemento, como por exemplo, na Hemocromatose Hereditária Juvenil (HHJ), que apresenta a concentração hepática de hepcidina significativamente reduzida. OBJETIVO: Determinar as principais mutações no gene HAMP em indivíduos acometidos por HHJ, com base na literatura recente. METODOLOGIA: Trata-se de um estudo retrospectivo, com revisão bibliográfica a partir da busca por publicações indexadas nas bases de dados EMBASE, PubMed e SCOPUS, disponíveis para download, redigidas em Inglês e publicadas no recorte temporal de 2016 até 2019, auxiliado pelo Protocolo PRISMA (Preferred Reporting Items for Systematic Reviews and Meta-Analyses). RESULTADOS E DISCUSSÃO: A HHJ é um distúrbio caracterizado pela absorção intestinal aumentada de ferro na dieta. Sem intervenção terapêutica, a sobrecarga deste metal leva a danos em múltiplos órgãos, desde pigmentação da pele a casos de cirrose hepática. Diante da leitura e análise dos 19 artigos constituintes da amostra final, 84,2\% ( $n=16)$ destes afirmaram que a deleção de uma guanina na posição 93 do gene HAMP (93delG) e a substituição C/T na posição 166 no éxon 3 são as alterações genéticas mais frequentemente associadas à HHJ. Ambas as mutações acarretam na codificação de uma pró-hepcidina de 179 resíduos de aminoácidos com pontes de cisteína incompatíveis, alterando o sítio de ligação da enzima pró hormônio convertase, produzindo uma pró-hepcidina truncada que não possui a sequência peptídica completa. Este truncamento impede a ligação da hepcidina à ferroportina, com consequente diminuição da hepcidina sérica. Todavia, 73,7\% dos artigos $(n=14)$ ressaltam que tais mutações são raras e que outras possíveis alterações sejam latentes, em decorrência da falta de mais pesquisas nesta área. CONCLUSÃÕ: A HHJ se configura como uma doença autossômica recessiva com duas alterações bastante consolidadas como cerne do problema. Porém, a mesma literatura que imprime tal afirmação reforça o incentivo à realização de novas pesquisas frente ao gene $H A M P$, a fim de uma melhor compreensão sobre a fisiopatologia da doença.

\section{Palavras-chave: Ferro; Hemocromatose; Mutação.}

\section{Referências}

FILLEBEEN, Carine et al. Transferrin receptor 1 controls systemic iron homeostasis by fine-tuning hepcidin expression to hepatocellular iron load. Blood, [s.1.], v. 133, n. 4, 
p.344-355, 24 jan. 2019. American Society of Hematology.

http://dx.doi.org/10.1182/blood-2018-05-850404.

LIU, Jing et al. Hepcidin. Medicine, [s.1.], v. 95, n. 14, p.1-13, abr. 2016. Ovid Technologies (Wolters Kluwer Health).

http://dx.doi.org/10.1097/md.0000000000003150.

MILIC, Sandra et al. The Role of Iron and Iron Overload in Chronic Liver

Disease. Medical Science Monitor, [s.1.], v. 22, p.2144-2151, 22 jun. 2016.

International Scientific Information, Inc.. http://dx.doi.org/10.12659/msm.896494.

RAMZAN, Khushnooda et al. Juvenile hemochromatosis and hepatocellular carcinoma in a patient with a novel mutation in the HJV gene. European Journal Of Medical Genetics, [s.1.], v. 60, n. 6, p.308-311, jun. 2017. Elsevier BV. http://dx.doi.org/10.1016/j.ejmg.2017.03.011.

REICHERT, Cadiele Oliana et al. Hepcidin: Homeostasis and Diseases Related to Iron Metabolism. Acta Haematologica, [s.1.], v. 137, n. 4, p.220-236, 2017. S. Karger AG. http://dx.doi.org/10.1159/000471838. 


\section{Principais Marcadores Genéticos Utilizados no Diagnóstico da Doença de Alzheimer}

${ }^{1}$ Wellia Adriany Bernardo Vieira Santos; ${ }^{1}$ Fhillipe Ferreira Deodato da Silva; ${ }^{1}$ Raissa

Veras de Sousa; 1 Jade Oliveira Vieira; ${ }^{1}$ Fernando Mesquita de Sousa Lima; ${ }^{2}$ Aldenora Maria Ximenes Rodrigues.

${ }^{1}$ Graduando (a) em Biomedicina na Universidade Federal do Piauí - UFPI; ${ }^{2}$ Docente em Biomedicina na Universidade Federal do Piauí - UFPI.

\section{RESUMO}

INTRODUÇÃO: A doença de Alzheimer é um distúrbio neurodegenerativo que se manifesta como um declínio progressivo da função cognitiva e é a causa de demência mais frequente no mundo. Aproximadamente $95 \%$ dos casos tem início depois dos 65 anos, início tardio, e 5\% antes dessa idade, início precoce, que é diretamente relacionada a fatores genéticos. OBJETIVO: Sintetizar os principais marcadores genéticos da doença de Alzheimer e relaciona-los com o diagnóstico genético. METODOLOGIA: Foram avaliados 12 artigos provenientes dos bancos de dados Medline e Google acadêmico, utilizando os descritores: Marcadores genéticos e Alzheimer, com recorte temporal de 2008 a 2019 e que estavam disponíveis na íntegra. RESULTADOS E DISCUSSÃO: Com o aumento da influência genética na doença de Alzheimer são utilizados marcadores genéticos para determinar a predisposição para a patologia. Os principais marcadores da doença de início precoce são genes mutados, que causam alterações nas proteínas por eles codificadas. A associação entre a doença de Alzheimer de início precoce e mutações gênicas foi descrita para 5 genes diferentes. O primeiro deles, o Apolipoproteína $\mathrm{E}$ (APOE), que dentre suas isoformas, o $\varepsilon 4$ é o maior fator de risco genético para o desenvolvimento da doença de Alzheimer, pois ele promove a expressão de fatores inflamatórios e pessoas positivas para esse alelo apresentam $\beta$-amilóide e TAU aumentados no cérebro e declínio cognitivo acelerado. $O$ aumento característico de $\beta$ amilóide também pode ser associado com mutações nos genes PSEN1, PSEN2 e a proteína precursora de $\beta$-amilóide (APP), onde os dois primeiros apresentam mutações que aumentam a clivagem da proteína precursora de $\beta$-amilóide e o último aumenta a produção da proteína em questão devido as mutações de troca de aminoácido. Por fim, outro gene envolvido é o MAPT, o qual possui a mutação R406W que aumenta a fosforilação de TAU. Em relação ao diagnóstico da doença de Alzheimer realizado no Brasil, existem 4 grandes laboratórios que o realizam a partir do estudo de marcadores, são esses: o APOE, nos laboratórios Genoa Biotecnologia e Geneone, e o APP, PSEN1 e PSEN2, no Fleury e Albert Einstein. CONCLUSÃO: Os principais marcadores genéticos da doença de Alzheimer descrito nos artigos são: APOE, APP, MAPT, PSEN1 e PSEN2. Havendo similaridade com os marcadores utilizados no diagnóstico genético. No entanto, a heterogeneidade genética é muito grande, pois não existe somente um alelo causador para os casos, resultando na necessidade de grande cautela, quando a ideia é a aplicação do diagnóstico genético precoce.

\section{Palavras-chaves: Doença de Alzheimer; Marcadores genéticos.}

\section{Referências}

Emily RA, Peter KP. The clinical utility of gene testing for Alzheimer's disease.

Neurology International. Austrália. 2011. 
Lucatelli JF, et al. Genetic influence on early onset Alzeimer's disease. Rev Psiq Clín. 2009.

Nalini DJ, et al. Review of main genes and proteins associated with tau-positive frontotemporal dementia. Rev. Bras. Geriatr. Gerontol. Rio de Janeiro. 2015. 


\section{Monitoramento de Marcadores Moleculares de Resistência Antimalárica: Uma Revisão Bibliográfica}

${ }^{1}$ Jade Oliveira Vieira; ${ }^{1}$ Raissa Veras de Sousa; ${ }^{1}$ Wellia Adriany Bernardo Vieira Santos; ${ }^{1}$ Fhillipe Ferreira Deodato da Silva; ${ }^{2}$ Thiago Nobre Gomes.

${ }^{1}$ Graduandos do curso de Bacharelado em Biomedicina da Universidade Federal do Piauí - UFPI; ${ }^{2}$ Professor do curso de Bacharelado em Biomedicina da Universidade Federal do Piauí - UFPI.

\section{RESUMO}

INTRODUÇÃO: A malária por Plasmodium falciparum é a infecção parasitária mais frequente no mundo, e durante anos foi tratada com cloroquina (CQ). Porém, o surgimento de mutações de tolerância em genes do parasito dificultou o controle da doença em regiões endêmicas, resultando na adoção da terapia combinada à base de artemisina (ACT). Acredita-se que estas mutações sejam marcadores moleculares de resistência, permitindo o monitoramento da sensibilidade ao declínio do uso de CQ. OBJETIVO: Analisar a literatura científica a fim de compreender o monitoramento da eficácia das drogas antimaláricas, baseado na evolução de marcadores moleculares alvos dos medicamentos. METODOLOGIA: Trata-se de um estudo retrospectivo, com revisão bibliográfica a partir de publicações indexadas nas bases de dados SciELO, MEDLINE e LILACS. Utilizou-se como descritores de busca os termos "PFMDR", "PFCRT" e "resistência a medicamentos". Como critérios de inclusão, foram consideradas as pesquisas publicadas entre os anos de 2009 a 2019, redigidas em português e inglês, abordando o referido tema. RESULTADOS E DISCUSSÃ̃: Após leitura dos trabalhos encontrados inicialmente e exclusão daqueles que não se enquadravam aos critérios propostos, foram selecionados 19 artigos. Um dos principais medicamentos antimaláricos é a cloroquina, que age nos vacúolos digestivos do $P$. falciparum bloqueando a degradação da heme. Porém, seu uso extensivo acarretou no surgimento de cepas resistentes, sendo assim substituído pela artemisina. A resistência à cloroquina está principalmente relacionada a mutações no gene $P F C R T$, que codifica uma proteína de membrana dos vacúolos do parasito. Outro marcador que também confere resistência ao medicamento é o gene PFMDR-1, que codifica um homólogo da glicoproteína $\mathrm{P}$ e também está presente nos vacúolos. Estudos demonstraram que após a retirada da cloroquina houve uma expansão de parasitos novamente sensíveis à droga, e que mutações específicas em PFCRT (K76T) e PFMDR-1 (N86Y) têm sido usadas como marcadores moleculares para monitorar alterações de suscetibilidade ao $P$. falciparum e orientar as políticas terapêuticas. Pesquisas realizadas no Iêmen, utilizando 735 amostras sanguíneas e submetendo-as a métodos PCR e RFLP, concluíram que as mutações para PFMDR-1 permanecem com alta prevalência, acima de $50 \%$, indicando uma alta resistência sustentada, mesmo após 4 anos da mudança para artemisina. CONCLUSÃO: A compreensão de determinantes genéticos fornece evidências para a vigilância molecular de cepas de $P$. falciparum resistentes a medicamentos. A capacidade do parasito de desenvolver tolerância, assim como a ausência de vacina e de investimentos na produção de fármacos mais eficientes, faz a malária permanecer representando um problema global.

Palavras-chave: Antimaláricos; Malária; Resistência a medicamentos. 


\section{Referências}

BAMAGA, Omar et al. "Survey of chloroquine-resistant mutations in the Plasmodium falciparum pfcrt and pfmdr-1 genes in Hadhramout, Yemen". Acta Tropica. Vol 1449. 2015. Disponível em:

https://doi.org/10.1016/j.actatropica.2015.05.013. Acesso em: 24 de setembro de 2019.

HUANG, Bo et al. "Prevalence of crt and mdr-1 mutations in Plasmodium falciparum isolates from Grande Comore island after withdrawal of chloroquine." Malaria journal vol. 15,1 414. 2016. Disponível em: https://doi.org/10.1186/s12936-016-1474-4. Acesso em: 24 de setembro de 2019.

MAGHENDJI-NZONDO, Sydney ET AL. "Malaria in urban, semi-urban and rural areas of southern of Gabon: Comparison of the Pfmdr 1 and Pfcrt genotypes from symptomatic children." Malaria Journal. 15. 2016. Disponível em:

https://doi.org/10.1186/s12936-016-1469-1. Acesso em: 24 de setembro de 2019.

NJOKAH, Muturi J et al. "In vitro selection of Plasmodium falciparum Pfert and Pfmdr1 variants by artemisinin." Malaria journal vol. 15,1 381. 22 Jul. 2016, Disponível em: https://doi.org/10.1186/s12936-016-1443-y. Acesso em: 24 de setembro de 2019.

OCAN, Moses et al. "Persistence of chloroquine resistance alleles in malaria endemic countries: a systematic review of burden and risk factors." Malaria journal vol. 18,1 76. 12 Mar. 2019. Disponível em: https://doi.org/10.1186/s12936-0192716-z. Acesso em: 24 de setembro de 2019. 


\title{
Mecanismos Epigenéticos Envolvidos no Desenvolvimento do Lúpus Eritematoso Sistêmico: Uma Revisão Bibliográfica
}

\author{
${ }^{1}$ Ana Joérica Lopes Vieira; ${ }^{1}$ Excelsa Aline Mendes Fonseca; ${ }^{1}$ Romério de Oliveira \\ Lima Filho; ${ }^{2}$ Thiago Nobre Gomes. \\ ${ }^{1}$ Graduandos do curso de Bacharelado em Biomedicina da Universidade Federal do \\ Piauí - UFPI; ${ }^{2}$ Professor do curso de Bacharelado em Biomedicina da Universidade \\ Federal do Piauí - UFPI.
}

\section{RESUMO}

INTRODUÇÃO: O Lúpus Eritematoso Sistêmico (LES) é um distúrbio autoimune caracterizado por uma grande quantidade de anticorpos na circulação de pacientes junto a respostas imunes desreguladas. Seu quadro clínico é complexo, revelando uma variedade de sintomas. Danos inflamatórios a diversos sistemas orgânicos como respiratório, circulatório e renal, e problemas de pele e de visão são os mais relatados. Sua etiologia ainda permanece incerta, porém fatores como suscetibilidade genética e condições ambientais têm demonstrado papel na patogênese da doença. Além disso, a epigenética têm se apresentado como outro elemento de fundamental importância para o conhecimento das causas que levam ao LES. OBJETIVO: Analisar a literatura científica reunindo informações sobre os mecanismos epigenéticos envolvidos no desenvolvimento do LES. METODOLOGIA: Trata-se de um estudo retrospectivo, com revisão bibliográfica baseada inicialmente na estratégia PICO: P (pacientes: com LES), I (intervenção: alterações epigenéticas), C (comparação: não se aplica), $\mathrm{O}$ (desfecho: desenvolvimento do LES). A pesquisa foi realizada a partir de publicações indexadas na base de dados PubMed, disponíveis em inglês, português ou espanhol, e publicadas entre os anos de 2011 a 2019, guiada pelo Protocolo PRISMA (Preferred Reporting Items for Systematic Reviews and Meta-Analyses). RESULTADOS E DISCUSSÃO: Ao menos 50 genes já foram associados ao desenvolvimento do LES, e dentre estes, destacam-se o DNMT1 e o GADD45A. O primeiro é responsável por copiar os perfis de metilação de uma fita de DNA para outra nova, garantindo a herdabilidade de metil durante os ciclos celulares. Por outro lado, o segundo tem por função codificar proteínas que respondem a estresses ambientais, influenciando na expressão de células T CD4+. Na literatura, já foi descrito que fatores ambientais como exposição à luz ultravioleta e o tabagismo promovem alterações epigenéticas nestes genes, contribuindo para o aparecimento dos sintomas do LES. Mecanismos epigenéticos como metilação do DNA e presença de miRNA's dos genes em questão facilitam o desenvolvimento dessa desordem autoimune, na medida que desregulam as células do sistema imune, principalmente linfócitos $\mathrm{T}$, aumentando sua expressão e induzindo respostas imunológicas contra suas próprias células, levando ao aparecimento da sintomatologia da doença. CONCLUSÃO: O LES é uma patologia de caráter bastante heterogêneo e sua etiologia ainda representa um desafio para clínicos e pesquisadores. No entanto, as influências epigenéticas para desencadear a doença são incontestáveis. Observa-se ainda que pacientes com intensa exposição à luz solar e/ou fumantes ativos ou passivos tornam-se mais vulneráveis ao desenvolvimento desta desordem autoimune.

Palavras-chave: Expressão gênica; Doenças autoimunes; Linfócitos T. 


\section{Referências:}

KUNZ, Manfred. Lupus erythematosus. Part I: epidemiology, genetics and immunology. JDDG: Journal der Deutschen Dermatologischen Gesellschaft, v. 11, n. 8, p. 709-720, 2013.

LONG, Hai et al. The critical role of epigenetics in systemic lupus erythematosus and autoimmunity. Journal of autoimmunity, v. 74, p. 118-138, 2016.

WANG, Zijun et al. Translating epigenetics into clinic: focus on lupus. Clinical epigenetics, v. 9, n. 1, p. 78, 2017.

WU, Haijing et al. Dysregulation of cell death and its epigenetic mechanisms in systemic lupus erythematosus. Molecules, v. 22, n. 1, p. 30, 2017.

ZAN, Hong. Epigenetics in lupus. Autoimmunity. v. 47, n. 4, p. 213-214, 2014. 


\section{O Impacto dos Polimorfismos da CYP2D6 no Tratamento do Câncer de Mama com Tamoxifeno}

${ }^{1}$ Raissa Veras de Sousa; ${ }^{1}$ Jade Oliveira Vieira, ${ }^{1}$ Fhillipe Ferreira Deodato da Silva, 1Thalis Ferreira de Souza, ${ }^{1}$ Wellia Adriany Bernardo Vieira Santos, ${ }^{2}$ Thiago Nobre Gomes.

${ }^{1}$ Discente do curso de Bacharelado em Biomedicina da Universidade Federal do Piaú UFPI; ${ }^{2}$ Docente do curso de Bacharelado em Biomedicina da Universidade Federal do Piauí - UFPI.

\section{RESUMO}

INTRODUÇÃO: O câncer de mama é a segunda neoplasia maligna de maior incidência em mulheres, sendo considerado um problema de saúde pública mundial devido à sua elevada incidência e mortalidade. Para o tratamento quimioterápico, a droga mais comumente utilizada é o tamoxifeno, um receptor modulador de estrogênio, que se destaca por reduzir pela metade a taxa de recorrência do câncer de mama. Por sua vez, a CYP2D6, codificada pelo gene $C Y P 2 D 6$, é a enzima chave para a metabolização dessa droga. OBJETIVOS: Analisar a literatura científica reunindo informações sobre o impacto da farmacogenética no estudo e tratamento do câncer de mama. METODOLOGIA: Trata-se de um estudo retrospectivo, com revisão bibliográfica a partir de publicações indexadas nas bases de dados PubMed, Science Direct, Medline, Lilacs e Google Acadêmico. Utilizou-se como descritores de busca os termos "farmacogenética" e "câncer de mama", de forma isolada ou associados, tanto em inglês quanto em português. Como critérios de inclusão, foram consideradas as pesquisas publicadas entre os anos de 2005 a 2018, redigidas em português e inglês, abordando a referida temática. RESULTADOS E DISCUSSÃO: Dentre os vinte artigos encontrados inicialmente, oito foram excluídos por não atenderem os critérios selecionados, e doze constituíram a amostra final. A farmacogenética foi desenvolvida visando identificar as causas genéticas das diferenças de resposta farmacológica entre os indivíduos, e prever a eficácia dos medicamentos. No tratamento de câncer de mama, o tamoxifeno é considerado um fármaco de uso padrão na terapia hormonal. Apesar de seus benefícios cientificamente comprovados, a droga é conhecida por desencadear eventos adversos como o aumento do risco de câncer endometrial. Nesse panorama, a literatura mostrou que a atividade da enzima CYP2D6 também determina a eficácia da droga, bem como seus efeitos adversos. Em pacientes com câncer de mama que possuíam atividade enzimática reduzida, observou-se uma pior evolução clínica e menos efeitos adversos, em comparação àquelas com atividade enzimática aumentada. Considerando que o gene CYP2D6 é altamente polimórfico, as variações genéticas são frequentes e podem produzir um metabolizador intermediário ou fraco, reduzindo a eficácia do tamoxifeno. CONCLUSÃO: Mediante a identificação dos polimorfismos genéticos de forma rápida e eficiente, a farmacogenética apresenta-se como uma área promissora, permitindo uma melhor compreensão da interação entre o fármaco quimioterápico e a genômica tumoral nos casos de câncer de mama. Assim, a partir do conhecimento sobre o perfil genético de cada paciente, pode-se escolher o melhor tratamento de forma personalizada para cada indivíduo.

Palavras-chave: Farmacogenética; Neoplasias da Mama; Tamoxifeno. 


\section{Referências}

BATISTA, Fernanda de Lima. Avaliação da relação entre o perfil de segurança e a farmacocinética do tamoxifeno no tratamento do câncer de mama. 2018.

FARMACOGENÉTICOS, ALVOS. Farmacogenética e implicações terapêuticas no câncer de mama. Revista Brasileira de Cancerologia, v. 59, n. 3, p. 449-452, 2013.

KIYOTANI, Kazuma et al. Impact of CYP2D6* 10 on recurrence-free survival in breast cancer patients receiving adjuvant tamoxifen therapy. Cancer science, v. 99, n. 5, p. 995-999, 2008.

SCHROTH, Werner et al. Association between CYP2D6 polymorphisms and outcomes among women with early stage breast cancer treated with tamoxifen. Jama, v. 302, n. 13, p. 1429-1436, 2009.

TAN, Sing-Huang et al. Pharmacogenetics in breast cancer therapy. Clinical Cancer Research, v. 14, n. 24, p. 8027-8041, 2008. 


\section{O Papel do Enfermeiro no Aconselhamento Genético: Uma Breve Revisão de Literatura}

Ana Klara Rodrigues Alves ${ }^{1}$; Barbara Beatriz Lira da Silva ${ }^{1}$; Ana Kamila Rodrigues Alves $^{2}$; Ana Karla Rodrigues Alves ${ }^{3}$; Francisco Artur e Silva Filho ${ }^{4}$; Kelly Sivocy Sampaio Teixeira ${ }^{5}$.

${ }^{1}$ Acadêmicas de Enfermagem da Universidade Estadual do Piauí-UESPI; ${ }^{2}$ Acadêmica de Fisioterapia pela Universidade Federal do Piauí-UFDPar, ${ }^{3}$ Graduada em Biomedicina pela Universidade Federal do Piauí-UFPI; ${ }^{4}$ Professor adjunto da Universidade Estadual do Piauí; ${ }^{5}$ Professora temporária da Universidade Estadual do Piauí.

\section{RESUMO}

INTRODUÇÃO: O aconselhamento genético consiste em pesquisar a ação dos genes e sua influência nos caracteres humanos, e desta forma, esclarecer e orientar as famílias portadoras dessas afecções. A consulta genética é um processo de comunicação centrado em problemas humanos associados à ocorrência de riscos de um distúrbio genético em uma família. Este processo envolve tentativas da equipe multiprofissional, treinadas para auxiliar a pessoa ou família a: compreender o diagnóstico, o curso provável do distúrbio e a conduta disponível; entender o modo pelo qual a hereditariedade contribuiu para o desenvolvimento do distúrbio e o risco de recorrência em pacientes especificados; compreender as alternativas para se lidar com o risco de recorrência; escolher o curso de ação que pareça ser apropriado à pessoa em vista de seu risco. Os profissionais de enfermagem, geralmente, são os que têm uma interação bem próxima e direta com os pacientes, devido a isso a enfermagem poder ser um pilar muito importante no aconselhamento genético. OBJETIVO: Relatar a atuação do enfermeiro no aconselhamento genético. METODOLOGIA: Trata-se de uma breve revisão da literatura realizada através da Biblioteca Virtual de Saúde (BVS) e bases de dados Lilacs e Medline, a partir do cruzamento entre os descritores "Enfermagem", "aconselhamento genético". Foram selecionados seis artigos, publicados no período de 2008 a 2019. RESULTADOS E DISCUSSÃO: O enfermeiro pode realizar o aconselhamento genético, com a finalidade de orientar as pessoas e seus familiares em todas as questões pertinentes a possíveis alterações diagnosticadas, em que serão abordadas as formas de prevenção e de tratamento. Esse profissional também poderá contribuir para a elaboração de projetos de pesquisa que objetivem a melhoria da qualidade de vida da população. Durante as consultas de enfermagem realizada por profissionais capacitados, $\mathrm{o}$ aconselhamento genético pode aliviar a angústia e o sofrimento das pessoas portadoras de doenças genéticas e também de seus genitores, alertando-os sobre a existência, ou não, de risco de recorrência de doenças hereditárias. Além disso, quando detectado o problema, esse atendimento possibilita o conhecimento de um prognóstico e a realização de um planejamento consciente de prevenção dos agravos. CONCLUSÃO: A crescente demanda de pessoas que necessitam dos serviços de aconselhamento genético serve de alerta para melhorias nessa área. A capacitação do enfermeiro em genética e genômica pode ser uma estratégia para melhoria na profilaxia, diagnóstico e tratamento, contribuindo para a diminuição nos índices de morbidade e mortalidade ligados às doenças genéticas.

Palavras-chave: Enfermagem, Aconselhamento genético, genética. 


\section{Referências}

CARDOSO, M.C.V., JÚNIOR, D.A.C. Enfermagem em genômica: o aconselhamento genético nas práticas assistenciais. REME • Rev Min Enferm., v.20, p.956,2016.

PROLLA, C.M.D., SILVA, P.S., NETTO, C.B.O,, et al. Conhecimento sobre câncer de mama e câncer de mama hereditário entre enfermeiros em um hospital público. Rev. Latino-Am. Enfermagem, v.23, n.1, p.90-7, jan.-fev. 2015.

SANTOS, M. F., SANTOS, E. M. M., NASCIMENTO, L.C., et al. Atuação do enfermeiro em oncologia na perspectiva da genética e genômica. Texto Contexto Enferm,v.22, n.2, p. 526-33. Florianópolis Abr-Jun, 2013. 


\section{A Importância do PCNA como Marcador Tumoral em Pacientes com Câncer Ovariano}

${ }^{1}$ Gustavo Oliveira Monteiro Alves; ${ }^{1}$ Jéssica Maria de Jesus Ferreira da Silva; ${ }^{1}$ Nicolle Barreira Maciel, ${ }^{2}$ Maria de Jesus Pereira Gomes; ${ }^{2}$ Dandara Maria Silva Araújo;

${ }^{3}$ Luciana Rocha Faustino.

${ }^{1}$ Graduando (a) em Biomedicina na Universidade Federal do Delta do Parnaíba UFDPar; ${ }^{2}$ Graduanda em Licenciatura em Ciências Biológicas na Universidade Federal do Delta do Parnaíba - UFDPar; ${ }^{3}$ Professora adjunta em Medicina na Universidade Federal do Delta do Parnaíba - UFDPar.

\section{RESUMO}

INTRODUÇÃO: Em razão do alto nível de incidência e taxa de mortalidade de cânceres, são realizados novos estudos para obter uma melhoria nos prognósticos da doença. Para sua identificação e acompanhamento são utilizados marcadores tumorais para monitorar a ação celular daquele tecido afetado. Entre esses marcadores, um que tem se mostrado efetivo é o antígeno nuclear de proliferação celular (PCNA), que é uma proteína relacionada diretamente à ação proliferativa das células, sintetizada durante a interfase do ciclo celular. Ele tem sido bastante utilizado como uma ferramenta para acompanhamento e avaliação da multiplicação de células tumorais. OBJETIVO: Avaliar a importância da expressão do PCNA e sua relação com a evolução clínica no acompanhamento de pacientes com câncer de ovário. METODOLOGIA: Foram analisados doze artigos disponibilizados nos bancos de dados do SciELO e PubMed. Como critérios de inclusão, foram analisados artigos em português e em inglês, publicados entre os anos de 2012 e 2019, restringindo a busca com os descritores "PCNA", "cancer" e "ovarian". E como critérios de exclusão, artigos duplicados, ausência de descritores no título e no resumo. RESULTADOS: Nos estudos analisados notou-se que o PCNA tem um importante papel como marcador tumoral, no qual foi utilizado no acompanhamento de pacientes com câncer de ovário, podendo também ser empregado em outros, como o de bexiga, mamas e pâncreas. O PCNA é essencial para a função da DNA polimerase $\delta$ e $\varepsilon$, que são responsáveis pela replicação e reparo de moléculas de DNA, e, por isso, quando se expressam em grandes números, se torna um indicativo de uma alta taxa de proliferação celular. Devido a isso, células que apresentam uma quantidade elevada de PCNA são indicativas de câncer, por vezes ainda podendo estarem relacionadas com metástase. Além da análise imuno-histoquímica para quantificação do PCNA também se utilizam outros marcadores tumorais para confirmar a presença de uma neoplasia no ovário, como o CA-125, que é outro marcador tumoral bastante importante no diagnóstico desse câncer e a proteína p53. CONCLUSÃO: A utilização do PCNA demonstrou ser uma importante ferramenta para a avaliação da progressão clínica da doença além de também auxiliar no diagnóstico precoce da mesma. Para um diagnóstico mais confirmatório, deve se utilizar também outros marcadores tumorais em conjunto com o PCNA, como o CA-125 e a análise da expressão da proteína p53.

\section{Palavras-chaves: PCNA; Neoplasias; Prognóstico.}




\section{Referências}

ANIOL, V. The effects of prolonged formalin fixation on immunohistochemical staining of PCNA and Dcx proteins in the mouse hippocampus. Neurochemical Journal, v. 10, n. 3 , p. $244-247,2016$.

DELKHOSH, A. et al. Upregulation of FSHR and PCNA by administration of coenzyme Q10 on cyclophosphamide-induced premature ovarian failure in a mouse model. Journal of Biochemical and Molecular Toxicology, v. 33, n. 11, 2019.

KUCHENBAECKER, K. et al. Identification of six new susceptibility loci for invasive epithelial ovarian cancer. Nature Genetics, v. 47, n. 2, p. 164-171, 2015.

PHOOPHITPHONG, D. et al. The use of proliferating cell nuclear antigen (PCNA) immuno-staining technique to determine number and type of follicles in the gilt ovary. Livestock Science, v. 150, n. 1-3, p. 425-431, 2012. 


\title{
Química Prebiótica e a Formação das Primeiras Moléculas Informacionais: Uma Revisão Bibliográfica
}

\author{
${ }^{1}$ Daniele Alcoforado Costa, ${ }^{1}$ Maria Rikelly Frota Aguiar, ${ }^{1}$ Lenilson do Nascimento \\ Melo Junior, ${ }^{1}$ Leonara Maria Alves Coelho, ${ }^{1}$ Grazielle Araujo dos Santos, ${ }^{1}$ Jaiane Cruz \\ dos Santos. \\ ${ }^{1}$ Graduando (a) em Biomedicina na Universidade Federal do Piauí - UFPI.
}

RESUMO

INTRODUÇÃO: Um dos principais focos para o entendimento da origem da vida na Terra remonta à formação de moléculas-chave em meio a química prebiotica de 4 bilhões de anos atrás. Diversos experimentos já realizados, desde a década de 50, demonstraram a formação de moléculas orgânicas mais complexas a partir de moléculas mais simples e inorgânicas e diversas teorias atualmente convergem para a ideia do surgimento das moléculas de RNA, DNA e proteínas como as pioneiras, que ao longo do processo evolutivo, possibilitariam a geração dos primeiros organismos vivos. OBJETIVO: Analisar a literatura científica a fim de reunir alguns dos principais estudos acerca da formação das moléculas precursoras de informação e da vida, bem como apresentar o embasamento científico dos mesmos, fornecido pelos dados e experimentos realizados nos últimos anos. METODOLOGIA: Foi realizada uma revisão da literatura a partir da busca de artigos na língua inglesa, durante o período de 2012 a 2019, disponibilizados nas bases de dados SciELO e PubMed. A busca resultou em 20 artigos e para inclusão destes foram utilizados os descritores "RNA", "prebiotic" e "origin of life". RESULTADOS E DISCUSSÃO: Muitos estudos defendem o ambiente aquático (caldo prebiótico) primeiro favoreceu a formação de ácidos nucleicos autorreplicativos e que outros elementos, como as proteínas, foram adicionados depois a esse sistema. Nesse contexto, uma das teorias de maior destaque é a que ficou conhecida como "Mundo do RNA", proposta na década de 60, onde o RNA surgiu primeiro e posteriormente deu origem ao DNA. É embasada principalmente pela propriedade do RNA de atuar tanto como molécula carregadora de informação como também catalisadora para formação de novas moléculas. Porém existem dificuldades para se reproduzir em laboratório cadeias de RNA, pois aponta-se que a força de ligação entre as duas cadeias emparelhadas não favoreceria a replicação para formação de novas cadeias. Krishnamurthy e Bhowmik, em 2016, propuseram então uma molécula híbrida, composta por fragmentos de RNA e DNA. Essas quimeras formavam complexos de fita dupla menos estáveis e que, durante o processo de replicação, sintetizaram cadeias puras de RNA e DNA mais facilmente. Chatterjee et al., em 2019, desenvolveram modelos que apontavam para moléculas de RNA e polipeptídeos como complementares. Esse complexo RNA-peptídeo foi primeiro desenvolvido na década de 70, de modo que funcionaria em um mecanismo de feedback, para a formação de aminoácidos e nucleotídeos. CONCLUSÃO: Existem muitas outras hipóteses que seguem caminhos distintos, apresentando diferentes moléculas como precursoras. Assim, observa-se que o conhecimento sobre as vias químicas para a formação das moléculas originárias ainda carece de mais estudos e dados experimentais, que tornariam mais concretos os conhecimentos existentes. Isso se torna fundamental para a compreensão não apenas da origem da vida, mas também da química das moléculas de ácidos nucleicos e seus mecanismos regulatórios.

Palavras-chave: origem da vida, RNA, química prebiótica 


\section{Referências}

GRABOW, Wade W.; ANDREWS, Grace E. On the Nature and Origin of Biological Information: The Curious Case of RNA. Biosystems, p. 104031, 2019.

HERNÁNDEZ, Armando R.; PICCIRILLI, Joseph A. Chemical origins of life: Prebiotic RNA unstuck. Nature chemistry, v. 5, n. 5, p. 360, 2013.

HIGGS, Paul G.; LEHMAN, Niles. The RNA World: molecular cooperation at the origins of life. Nature Reviews Genetics, v. 16, n. 1, p. 7, 2015. 


\section{O Uso de Recursos Didáticos por Professores de Biologia no Ensino de Genética}

${ }^{1}$ Junielson Soares da Silva; ${ }^{2}$ Emyraldo Stéfano Ferreira Lima; ${ }^{3}$ Marilha Vieira de Brito.

${ }^{1}$ Mestre em Genética, Conservação e Biologia Evolutiva, no Instituto Nacional de Pesquisas da Amazônia e Professor da Seduc-PI; ${ }^{2}$ Médico Programa Mais Médicos do Brasil, Caxias-MA; ${ }^{3}$ Mestre em Genética e Melhoramento(PPGM) na Universidade Federal do Piauí - UFPI.

\section{RESUMO}

INTRODUÇÃO: Os conceitos de genética são de difícil assimilação pelos alunos, uma vez que se apresentam de forma abstrata. Estudos relatam que o ensino de genética ainda é realizado de forma tradicional, com o uso de metodologias passivas que pouco auxiliam na aprendizagem. $\mathrm{O}$ uso de diversos recursos didáticos (RDs), como jogos e modelos didáticos, experimentos científicos, vídeos, filmes, músicas, cartazes, dentre outras alternativas metodológicas favorecem o aluno na apreensão de conceitos e na aquisição de conhecimentos de genética. OBJETIVO: Investigar o uso de recursos didáticos no ensino de genética, por professores de Biologia, como instrumentos facilitadores de aprendizagem. METODOLOGIA: Um questionário contendo 10 perguntas foi elaborado no Google Formulário e postado no grupo de WhatsApp Professores biologizando. Solicitou aos participantes do grupo, que são professores de biologia no ensino médio em diversas partes do país, que o respondessem, após um mês analisou-se os resultados. RESULTADOS E DISCUSSÃO: De 15 participantes, 54\% eram do sexo masculino, existindo pessoas da região Nordeste, Sudeste, Centro-Oeste e Norte. Do total, 93\% possui licenciatura e 7\% bacharel, todos formados em Biologia, 27\% deles possui somente graduação, $40 \%$ especialização, $20 \%$ mestrado e $13 \%$ doutorado. Quanto aos recursos didáticos $(\mathrm{RD})$ no ensino de genética, $60 \%$ afirmaram que às vezes usam, $33 \%$ disse que sempre usa e 7\% nunca usa. Os RD mais utilizados são livro didático (67\%), datashow (60\%), quadro/pincel (46\%), alguns fazem uso de experimentos práticos (33\%), jogos didáticos e recursos audiovisuais (26\%) ou usam modelos didáticos e revistas e jornais $(20 \%)$. Fora da classe, os professores afirmaram que utilizam livros digitais (53\%) e impressos (47\%), WhatsApp (40\%), sites de resumos e jogo didático digital (26\%), além de sites de quizes e perguntas (13\%). Os RDs usados pelos professores são em sua maioria encontrados na internet $(60 \%)$, alguns produzem o próprio material didático (20\%) ou pesquisam em livros e revistas (20\%). Observou-se o uso de tecnologias como novos RD's, mas ainda há professores que não aderiram a essas ferramentas. Contudo, $100 \%$ deles reconhecem a importância desse recurso para aprendizagem dos conceitos de genética. CONCLUSÃO: O uso de RD's por professores, para ensinar conceitos de genética no ensino médio ainda é limitado, mesmo eles percebendo o valor dessa ferramenta. No entanto, novas tecnologias didáticas estão sendo implementadas em sala de aula, para o ensino aprendizagem desse conteúdo.

Palavras-chave: Recursos didáticos; Aprendizagem; Genética

\section{Referências}

BARROS, G. D.; RIBEIRO, A. M.; SILVA, D. M. S. O uso de Recursos Didáticos no Ensino de Genética: Investigando as Produções Acadêmicas Nacionais. In: Anais XI ENPEC, 2017, Florianópolis. XI ENPEC, p. 1-9, 2017. 
NASCIMENTO, J. M. T. S. , CAMPOS, F. L. . A importância da utilização de recursos didático-pedagógicos no ensino de genética em escolas públicas no Municipio de Parnaíba - PI (Brasil). Espacios (Caracas), v. 39, p. 30, 2018.

SILVA, J. S. Extração de DNA de cebola (Allium cepa) por alunos de uma escola estadual de Teresina-PI, como complemento no ensino de Genética. Revista Científica Semana Acadêmica, v. 1, p. 1-10, 2019.

SILVA, J. S.; FONTES, L. S. Combatendo os nematelmintos parasitas: jogo didático para facilitar a aprendizagem. Revista Eletrônica Ensino, Saúde e Ambiente, v. 10, p. 127-143, 2018.

SILVA, J. S.; DANTAS, S. M. M. M. Conhecendo as parasitoses do brasil: jogo de tabuleiro. Revista da SBEnBIO, v. 7, p. 4328-4338, 2014. 


\section{Relação entre Matemática e Leis de Mendel em uma Escola Pública de Parnaíba- PI}

${ }^{1}$ Francisco da Chagas de Araújo Mota Filho; ${ }^{1}$ José Rodolpho de Sousa Lopes; ${ }^{1}$ Eduardo das Chagas Machado; ${ }^{2}$ Francilene Leonel Campos.

${ }^{1}$ Graduando em Ciências Biológicas na Universidade Federal do Piauí - UFPI;

${ }^{2}$ Professora Associada em Ciências Biológicas na Universidade Federal do Piauí UFPI.

\section{RESUMO}

INTRODUÇÃO: A biologia é uma área que passa por constantes mudanças, e possui um caráter interdisciplinar muito forte. A Genética, assim como outras ciências, não surgiu ao acaso; a mesma apresenta aspectos dos conceitos e aplicações da matemática. Foi a partir dos experimentos de Gregor Mendel no século XX com ervilhas, que ele pôde elaborar teorias a respeito das bases da hereditariedade, e foi com esses experimentos que ele ressaltou a aplicação de determinados conteúdo da matemática na genética, quando percebeu que havia um padrão básico de estatística na hereditariedade dos indivíduos. OBJETIVO: Analisar a relação entre os conhecimentos matemáticos e genéticos especificamente de Leis de Mendel - dos alunos do terceiro ano do ensino médio em uma escola pública de Parnaíba-PI. METODOLOGIA: Foi aplicado um questionário contendo oito questões, sendo $50 \%$ questões estritamente matemáticas e $50 \%$ questões de genética sobre as leis de Mendel. A pesquisa foi direcionada aos alunos de duas turmas de terceiro ano do ensino médio de uma escola pública, na cidade de Parnaíba-PI, devido aos conteúdos de genética serem mais expressivos nessa fase do ensino básico. RESULTADOS E DISCUSSÃO: A pesquisa resultou na participação de um total 50 alunos, onde $66 \%$ dos participantes mostraram uma relação positiva entre os conhecimentos estritamente matemáticos e sobre leis de Mendel. Este resultado é compatível com os trabalhos de Araújo et al. (2018) e de Santos Filho, Alle e Leme (2018). Outro resultado obtido foram as diferenças na proporção de acertos nas duas classes; acredita-se que isso se deve ao ensino deficiente de genética em uma das turmas. Esta hipótese é corroborada por dois fatos: 1- docentes distintos ministraram os conteúdos, nas classes; 2- houve uma diferença de 39,8\% de acertos, nas duas turmas, nas questões de genética. CONCLUSÃO: Há uma relação positiva entre a base de conhecimentos matemáticos e os saberes sobre leis de Mendel. Apesar da deficiência nos conhecimentos de genética em parte dos dados, a relação total ainda se revelou acima do valor médio, mostrando que a interdisciplinaridade em genética é muito importante para sua compreensão e aplicação.

\section{Palavras-chave: Genética; Matemática; Educação.}

\section{Referências}

ARAÚJO, M. S.; FREITAS, W. L. S.; LIMA, S. M. S.; LIMA, M. M. O. A genética no contexto de sala de aula: dificuldades e desafios em uma escola pública de Floriano-PI. REnCiMa, v. 9, n. 1, p. 19-30, 2018.

BORGES, C. K. G. D.; SILVA, C. C.; REIS, A. As dificuldades e os desafios sobre a aprendizagem das leis de Mendel enfrentados por alunos do ensino médio. Experiências em Ensino de Ciências, v. 12, n. 6, 2017.

SANTOS FILHO, R.; ALLE, L. F.; LEME, D. M. Diagnosticando dificuldades no processo de ensino-aprendizagem de genética nas escolas e universidades. Olinda - V CONEDU, 2018. 


\title{
Reposição de Estrogênio e o Risco de Câncer Endometrial em Pacientes com Polimorfismo no Citocromo p450
}

\author{
${ }^{1}$ Fhillipe Ferreira Deodato da Silva; ${ }^{1}$ Wellia Adriany Bernardo Vieira Santos; ${ }^{1}$ Raissa \\ Veras de Sousa; ${ }^{1}$ Jade Oliveira Vieira; ${ }^{1}$ Samara Marques de Oliveira; ${ }^{2}$ Even Herlany \\ Pereira Alves.
${ }^{1}$ Graduando (a) em Biomedicina na Universidade Federal do Piauí - UFPI; ${ }^{2}$ Pós- graduanda em Biotecnologia na Universidade Federal do Piauí - UFPI.

\section{RESUMO}

INTRODUÇÃO: O câncer endometrial é o principal câncer ginecológico e afeta principalmente as mulheres na pós-menopausa. A reposição hormonal para alívio dos sintomas menopausais é amplamente utilizada em todo o mundo. Na década de 70, ocorreu um aumento de incidência de câncer endometrial relacionada, principalmente, a terapia de reposição estrogênica isolada. Estudos demonstraram que reposição de estrogênio isolado tem desenvolvido câncer endometrial em mulheres com polimorfismos no sistema enzimático do citocromo P-450. OBJETIVO: Realizar uma busca por estudos que abordem uma relação à associação de reposição de estrogênio com polimorfismos no citocromo P-450 e o risco de câncer endometrial e como esse risco pode ser reduzido. METODOLOGIA: Realizou-se uma busca nos bancos de dados Medline, Pubmed, Google Scholar, utilizando os descritores: "câncer endometrial", "polimorfismos" e "citocromo P-450". Foram excluídos artigos que não concordavam com o tema e que não estavam disponíveis na íntegra. RESULTADOS E DISCUSSÃO: Após aplicação dos critérios de exclusão, resultou-se em doze artigos. A terapia de reposição estrogênica isolada é administrada em mulheres na pós-menopausa e aumenta o risco de câncer endometrial. O citocromo P-450 é importante para a biotransformação de vários compostos endógenos e exógenos, este apresenta considerável variabilidade genética que pode afetar a eficácia deste sistema e produzir efeitos adversos. O gene CYP1B1 desempenha um papel importante no metabolismo e na manutenção do equilíbrio de estrogênio. Observou-se em um estudo feito com pacientes com câncer endometrial que o polimorfismo L432V no gene CYP1B1 está correlacionado com a suscetibilidade ao câncer endometrial, uma vez que polimorfismos podem ser herdados. Associações estatisticamente significativas ao câncer endometrial foram observadas com genótipos que continham qualquer alelo CYPlAl *2C, em comparação com genótipos sem alelo $* 2 \mathrm{C}$ em mulheres que realizavam terapia estrogênica. Em outro estudo, foi examinada uma associação entre risco de câncer endometrial e terapia estrogênica pelo genótipo CYP17, usando casos incidentes de câncer endometrial e controles. Observouse que as mulheres que relataram realizar terapia estrogênica tinham duas vezes mais chances de desenvolver câncer endometrial do que as mulheres que nunca usaram terapia estrogênica, o risco era maior para mulheres homozigotas para o alelo $C Y P 17 T$. CONCLUSÃO: $O$ uso de terapia de reposição estrogênica isolada aumenta o risco de câncer endometrial, porém, mulheres com polimorfismos no citocromo P-450 têm um risco maior para o desenvolvimento dessa neoplasia, sendo assim, se faz necessário que esta terapia seja combinada com progesterona para diminuir o risco de desenvolvimento desse câncer. 
Palavras-chave: Neoplasias do Endométrio, Citocromo P-450, Polimorfismo Genético.

Referências

McKean-Cowdin R, et al. Risk of endometrial câncer andestrogen replacement therapy history by CYP17 genotype. Cancer Research. 2001.

RobertaMC, et al. Declining Cancer Ratesin the 1990s. Journal of Clinical Oncology 2000.

Timothy RR, et al. Estrogen Sulfation Genes, Hormone Replacement Therapy, and Endometrial Cancer Risk. Journal of the National Cancer Institute. 2006. 


\section{Screening Toxicológico do Extrato Etanólico da Flor de Pityrocarpa moniliformis (Benth) através do Bioensaio Artemia salina (Leach)}

Junaiza Rodrigues Lima; ${ }^{1}$ Shamya Gabriella Corrêa Coêlho, ${ }^{1}$ Glíssia Lysandra dos Santos Marciel; ${ }^{2}$ João Sammy Nery Souza; ${ }^{3}$ Aldeídia Pereira de Oliveira; ${ }^{4}$ Elisângela Claudia Alves de Oliveira.

${ }^{1}$ Graduanda em Ciências Biológicas na Universidade Federal do Piaú UFPI(Floriano); ${ }^{2}$ Professor Associado do Departamento de Química (CCN) da

Universidade Federal do Piauí UFPI (Teresina); ${ }^{3}$ Professora Associada do Departamento de Biofísica e Fisiologia (CCS) da Universidade Federal do Piauí- UFPI (Teresina); ${ }^{4}$ Professora Adjunta do Curso de Ciências Biológicas da Universidade Federal do Piauí UFPI (Floriano).

\section{RESUMO}

INTRODUÇÃO: A espécie Pityrocarpa moniliformis (Benth), popularmente conhecida como angico de bezerro ou quipembe, é uma espécie de crescimento rápido, encontrada nos estados brasileiros do Maranhão, Piauí, Ceará e Bahia. Os estudos que caracterizam esta espécie quanto as suas atividades biológicas têm demonstrado propriedades importantes, como atividade antimicrobiana e antioxidante, o que justifica o seu uso pela população. OBJETIVO: O presente trabalho teve como objetivo avaliar o perfil toxicológico do extrato etanólico da flor de Pityrocarpa moniliformis (Benth) através do bioensaio Artemia salina (Leach). METODOLOGIA: Inicialmente os cistos de Artemia salina foram colocados para eclodir em uma solução de $1 \mathrm{~L}$ de água destilada para $36 \mathrm{~g}$ de $\mathrm{NaCl}$ sob iluminação e aeração constante, durante 48 horas. Posteriormente, os náuplios eclodidos foram separados com pipetas Pasteur e 10 larvas de A. salina foram transferidas para tubos de ensaio com concentrações que variavam de $0,1 \mu \mathrm{g} / \mathrm{ml}$ a $1000 \mu \mathrm{g} / \mathrm{ml}$ do extrato etanólico da flor de pityrocarpa moniliformis (Benth). Durante a etapa de tratamento, os tubos com as Artemias foram mantidos em temperatura ambiente e sob presença constante de luz, durante 24 horas, dentro de uma capela de fluxo laminar. Todos os testes foram feitos em triplicata e comparados ao controle negativo. Após esse período, procedeu-se a contagem do número de organismos que permaneceram vivos e com mobilidade inalterada e posteriormente foi feito um cálculo indicando o percentual de mortalidade das Artemias salina (Leach). A análise estatística foi realizada com o teste T student e análise de variância (ANOVA) com valores de $p$ inferiores a 0,05. RESULTADOS E DISCUSSÃO: Os resultados demonstraram um aumento na taxa de mortalidade de aproximadamente $30 \%$ para a concentração de $243 \mu \mathrm{g} / \mathrm{ml}$ e para as concentrações de $500 \mu \mathrm{g} / \mathrm{ml}, 750 \mu \mathrm{g} / \mathrm{ml}$ e $1000 \mu \mathrm{g} / \mathrm{ml}$ o percentual de mortalidade foi de $100 \%$. Devido à alta sensibilidade deste bioensaio, ele vem sendo muito utilizado no direcionamento de estudos fitoquímicos, na busca de novas substâncias bioativas e também, servem de triagem para escolha de concentrações a serem utilizadas em testes de citogenotoxicidade. CONCLUSÃO: Portanto, diante dos resultados obtidos, pode-se concluir que o extrato etanólico da flor de Pityrocarpa moniliformis (Benth) é citotóxico nas concentrações mais elevadas, ao menos no bioensaio utilizado. Entretanto, mais estudos serão realizados com o intuito de confirmar essa toxicidade e de avaliar a citotogenotoxidade do extrato etanólico da flor de Pityrocarpa moniliformis (Benth).

Palavras-chave: Morte celular. Angico de Bezerro. Artemia salina (Leach). 


\section{Referências}

BENEDITO, P. C. Armazenamento e viabilidade de sementes de Catanduva (Piptadenia moniliformis Benth). 63f. Dissertação (Mestrado em Fitotecnia) Universidade Federal Rural do Semi-Árido, Mossoró, 2010.

MEYER, B. N.et al. A conveniente general bioassay for active plant constituents. Planta Medica,v.45,p.31-34, 1982.

ROCHA,Tamiris Alves et al. Avaliação da atividade Hemolítica dos extratos orgânicos de Pityrocarpa moniliformis. Combracis, 2019. 


\section{Diversidade Gênica em Isolados do Gênero Leishmania: Uma Revisão Literária}

${ }^{1}$ Naira Celeste da Costa Ferreira; ${ }^{1}$ Philipe Veras Pires; ${ }^{2}$ Ana Karoline da Costa Ferreira;

${ }^{1}$ LucasFlorencia da Silva; ${ }^{1}$ Antônio Cleiton de Sousa; ${ }^{3}$ Dacylla Sampaio Costa

${ }^{1}$ Graduando (a) em Biomedicina na Universidade Federal do Piauí - UFPI; ${ }^{2}$ Graduando (a) em Biologia na Universidade Federal do Piauí; ${ }^{3}$ Pós-graduando em Ciências Biomédicas

\section{RESUMO}

INTRODUÇÃO: As leishmanioses são patogenias transmitidas por vetores, causadas por protozoários do gênero Leishmania (Trypanosomatida: Trypanosomatidae). São endêmicas em áreas tropicais, subtropicais e na bacia do Mediterrâneo, incluindo mais de 98 países. Os parasitas podem causar quatro formas clínicas da doença denominados: leishmaniose visceral, cutânea, cutânea difusa e mucocutânea. A variação genética dos parasitas de Leishmania pode resultar em diferentes fenótipos que podem estar associados à distribuição geográfica e diversidade das manifestações clínicas. Portanto, a compreensão das variantes gênicas da Leishmania é determinante para a previsão futura de padrões de transmissão de Leishmania, epidemiologia da leishmaniose e desenvolvimento de estratégias de intervenção e controle. OBJETIVO: Analisar a literatura científica explorando os polimorfismos genéticos em isolados de Leishmania visceral e tegumentar de hospedeiros humanos e animais METODOLOGIA: Trata-se de um estudo retrospectivo, com revisão literária a partir de publicações indexadas nas bases de dados SciELO, PubMed e Science Direct. Foram utilizados como descritores de busca os termos "Leishmania", "Host", "Polymorphism". Como critérios de inclusão, foram consideradas as pesquisas publicadas em um recorte temporal de 2003 a 2019, nos idiomas inglês, português e espanhol, as quais abordassem a temática proposta. RESULTADOS E DISCUSSÃO: Após leituras dos títulos, resumos e texto completo selecionou-se 13 artigos científicos para a confecção do presente estudo. Nos estudos selecionados relacionados à diversidade gênica foi observado as análises dos padrões de restrição de $N A G T$, os quais permitiram o agrupamento de isolados de L. infatum em seis genótipos distintos, quando comparados aos genótipos previamente estabelecidos, na literatura, para as espécies L. donovani e L. infantum. Além dessas Hamouchi e colaboradores (2018) relatou as variantes M98, M1, M2, M3, sendo que os últimos três citados foram observados somente no Marrocos. Nas análises filogenéticas relatadas foi observado que a maioria dos isolados corresponde ao genótipo comum de L.infatum, independente da origem geográfica, hospedeiro ou forma clínica. O gene observado em comuns estudos $N A G T$, é um gene de cópia única altamente conservado, que codifica a proteína transmembrana do retículo endoplasmático, está diretamente relacionado com a virulência da Leishmania. Ao observar as bibliografias foi observado que há uma variabilidade gênica entre cepas de Leishmania infatum. CONCLUSÃO: Notamos a importante heterogeneidade genética intraespecífica entre cepas $L$. infantum isoladas em humanos e animais. Isto pode ser explicado pelo extenso fluxo gênico e recombinação, associados à migração intensiva de hospedeiros e características epidemiológicas comum nos países endêmicos.

\section{Palavras-chave: Leishmania; Interações Hospedeiro-Parasita; Variação Biológica da População}




\section{Referências}

ALURU, Srikanth et al. Multilocus microsatellite typing of Leishmania and clinical applications: a review. Parasite, v. 22, 2015.

EL HAMOUCHI, Adil et al. Genetic polymorphism in Leishmania infantum isolates from human and animals determined by nagt PCR-RFLP. Infectious diseases of poverty, v. 7, n. 1, p. 54, 2018.

GOUZELOU, Evi et al. Genetic diversity and structure in Leishmania infantum populations from southeastern Europe revealed by microsatellite analysis. Parasites \& vectors, v. 6, n. 1, p. 342, 2013.

KUHLS, Katrin et al. Differentiation and gene flow among European populations of Leishmania infantum MON-1. PLoS neglected tropical diseases, v. 2, n. 7, p. e261, 2008.

TIRERA, Sourakhata et al. Unraveling the genetic diversity and phylogeny of Leishmania RNA virus 1 strains of infected Leishmania isolates circulating in French Guiana. PLoS neglected tropical diseases, v. 11, n. 7, p. e0005764, 2017. 


\section{“Jogo da Memória: Que Herança é essa?" como Instrumento Facilitador no Ensino de Genética}

${ }^{1}$ Marilha Vieira de Brito; ${ }^{2}$ Junielson Soares da Silva; ${ }^{3}$ Ana Paula da Silva Costa; Franciele de Sousa Santos; ${ }^{2}$ Dayane Vieira Lima; Gérson do Nascimento Costa ${ }^{1}$

${ }^{1}$ Mestre em Genética e Melhoramento (PPGM) na Universidade Federal do Piauí UFPI; ${ }^{2}$ Mestre em Genética, Conservação e Biologia Evolutiva, no Instituto Nacional de Pesquisas da Amazônia e Professor da Seduc-PI; ${ }^{3}$ Graduada em Licenciatura em Ciências Biológicas na Universidade Estadual do Maranhão-UEMA

\section{RESUMO}

INTRODUÇÃO: Os conteúdos de Genética muitas vezes são ditos pelos alunos como difíceis de aprender, seja por ser um ramo da biologia que estes alunos aleguem ter muitos cálculos, ou complexidade dos conceitos, neste caso trata-se de um ramo da biologia, que necessita de atividades que visem facilitar o aprendizado e assim modificar a visão que muitos desses alunos têm dessa área da biologia como "chata" e "difícil de aprender. A prática de atividades que ajudem a esclarecer muitos dos assuntos em Genética tem sido uma preocupação constante de muitos professores de biologia. Atualmente, os jogos didáticos têm ocupado cada vez mais espaço no campo educacional. OBJETIVO: Desenvolver de um jogo didático como forma de facilitar a aprendizagem quanto a conceitos importantes relacionados a herança genética. METODOLOGIA: o presente trabalho teve como público-alvo amostragem de 289 estudantes de ensino médio pertencentes a 03 (três) escolas, sendo 2 (duas) públicas estaduais situadas no município de Coelho Neto-MA; e uma particular, situado no município de Buriti-MA (os grupos foram caracterizados como $\mathrm{A}, \mathrm{B}$ e $\mathrm{C}$ respectivamente). Foi aplicado um questionário antes e após a explanação do jogo, afim de observar a eficiência do mesmo frente a obtenção de conteúdos relacionados herança genética. O jogo em questão possui 16 cartas, sendo que uma carta contém a definição da herança e seu respectivo par apresenta uma imagem e o nome da herança genética como mostra a figura a seguir. $\mathrm{O}$ aluno deverá montar o par de cartas de acordo com as principais heranças genéticas estudadas em Biologia no Ensino Médio. RESULTADOS E DISCUSSÃO: Durante a aplicação do jogo didático verificou-se que o mesmo possibilitou à socialização, a comunicação, a construção do conhecimento e também despertou o interesse dos alunos sobre os conteúdos de genética. Esses fatores provavelmente estão ligados a progressão quanto acertos, quando comparados pré e pós-teste. Os resultados deste estudo mostraram que a turma "A", no pré-teste, obteve $43 \%$ de acertos e após a aplicação do jogo, somou $53 \%$ no pós-teste. A turma "B", no pré-teste, teve um percentual de $57 \%$ de acertos nas questões, enquanto que no pós-teste os mesmos alunos apresentaram um percentual de acertos de $80 \%$. A turma " $C$ " alcançou $65 \%$ de acertos no pré-teste e após a utilização do jogo como proposta complementar, esse índice aumentou para $77 \%$ no pós-teste. CONCLUSÃO: Com a aplicação dos pré-testes e pós-testes, constatou-se um aumento nos índices percentuais de acertos após o uso do jogo didático. Estes resultados permitiram confirmar que a atividade lúdica realizada favoreceu a construção de uma aprendizagem significativa.

\section{Palavras-chave: Aprendizagem; Herança Genética; Jogo Didático.}




\section{Referências:}

COSTA, G. N. ; PEIXOTO, L. R. Padrões de Herança Biológica em Jogo. In: Mostra de Ciência e Tecnologia das Entidades Estudantis (UBES, UNE, ANPG), Pernambuco, 2013, Anais..., Pernambuco, p. 53-56.

GOMES, R.R.; FRIEDRICH, M.A. (2001). Contribuição dos jogos didáticos na aprendizagem de conteúdos de Ciências e Biologia. In: EREBIO,1, Rio de Janeiro, 2001, Anais..., Rio de Janeiro, p.389-392.

PAES, M. F.; PARESQUE, R. Jogo da Memória: Onde está o gene? Revista Genética na Escola. Rio de Janeiro, v.9 n.1 p. 29-26, 2009.

RIEDER, R.; ZANELATO, E.M.; BRANCHER, J.D. Observação e análise da aplicação de jogos educacionais bidimensionais em um ambiente aberto. IX TALLER INTERNACIONAL DE SOFTWARE EDUCATIVO São Paulo 2004, Anais... Rio de Janeiro, 2004. P. 61-66.

ZANON, D.A.V.; GUERREIRO, M.A.S.; OLIVEIRA; R.C. (2008). Jogo didático Ludo Químico para o ensino de nomenclatura dos compostos orgânicos: projeto, produção, aplicação e avaliação. Revista Ciências e Cognição, 13:72-81. 


\title{
Relação da Endogamia com Doenças Genéticas na Região Nordeste: Uma Revisão Bibliográfica \\ ${ }^{1}$ Airton Lucas Sousa dos Santos; ${ }^{2}$ Letícia da Silva Queiroz; ${ }^{3}$ Paloma Maria de Sousa Araujo; ${ }^{4}$ Lucas Florencia da Silva; ${ }^{5}$ Thalis Ferreira de Souza; ${ }^{6}$ Aldenora Maria Ximenes Rodrigues
}

1,2,3,4 Graduandos do Curso de Biomedicina pela Universidade Federal do Piauí, Campus Ministro Reis Velloso, Parnaíba-PI. ${ }^{6}$ Doutoranda em Biotecnologia- UFPI

(RENORBIO)

\begin{abstract}
RESUMO
INTRODUÇÃO: O Brasil é um dos pais com maior mistura racial, uma vez que o mesmo no tempo de colonização recebeu povos de diferentes partes do mundo, dentre eles os africanos, portugueses e espanhóis. Sendo assim, as regiões litorâneas eram os locais em que se tinham as maiores concentrações de pessoas, por conta do desembarque dos navios, principalmente a região nordeste. OBJETIVO: Analisar a literatura científica reunindo informações que descrevam sobre a relação da consanguinidade e doenças genéticas em regiões brasileiras. MÉTODOS: Trata-se de um estudo retrospectivo, por meio de uma revisão literária a partir de publicações indexadas nas bases de dados SciELO e PubMed. Utilizou-se como descritores de busca os termos "epidemiologia", "endogamia", "consanguinidade" e "genética", de forma isolada e associada, tanto em inglês quanto em português. Como critérios de inclusão, foram consideradas as pesquisas publicadas no recorte temporal de 2012 a 2018, disponíveis na íntegra, abordando a referida temática. RESULTADOS: Após leitura de 26 trabalhos, foram selecionados 10 artigos. A partir disto foi possível observar que o casamento consanguíneo é um dos grandes fatores que influencia no aumento da frequência de doenças genéticas nas populações, tal fator ocorre por conta diversas variantes, dentre elas pode-se destacar questões culturais e o isolamento geográfico, decorrente da baixa taxa de imigração. Por conta disso, a frequência de alelo recessivos se encontrarem é muito maior, pois há pouca variabilidade genética. Dados mostram que a região nordeste é a que possui maior frequência de pessoas com deficiências relacionadas tanto a fatores genéticos como outros que desenvolvem tais patologias. Dentre elas destacam-se a Paraíba $(18,76 \%)$ se tornando a cidade com maior frequência, em seguida temos Rio Grande do Norte (17,64\%), Piauí $(17,63 \%)$, Pernambuco $(17,4 \%)$ e Ceará $(17,3 \%)$. No estado do Piauí a frequência de pessoas com anemia falciforme é muito grande, sendo que pessoas afrodescendentes possuem maior acometimento, e $0,3 \%$ da população com descendência negra é encontra no Piauí, Maranhão e Bahia. Visto que as pessoas acometidas se encontram em regiões de baixa renda, o tratamento e aconselhamento genético se tornam difíceis, em consequência da falta de profissionais. CONCLUSÃO: O presente trabalho demonstrou que a região nordestina é a que possui maior frequência de pessoas com doenças genéticas, ligado principalmente por conta do casamento consanguíneo. Foi possível observar que existem poucos estudos e que os mesmos não são atuais, desta forma a frequência das doenças devem possuir uma porcentagem maior.
\end{abstract}

\section{Palavras-chave: Epidemiologia; Endogamia; Cruzamento consanguíneo.}




\section{Referências:}

SANTOS, Silvana Cristina dos et al. A endogamia explicaria a elevada prevalência de deficiências em populações do Nordeste brasileiro? Ciênc. Saúde coletiva, Rio de Janeiro, v. 18, n. 4, p. 1141-1150, Apr. 2013

SOARES, Leonardo Ferreira et al. Prevalência de hemoglobinas variantes em comunidades quilombolas no estado do Piauí, Brasil. Ciênc. Saúde coletiva, Rio de Janeiro, v. 22, n. 11, p.3773-3780, nov. 2017.

SOARES, Marina Tanieri de Oliveira. Estimativa da consanguinidade e ocorrência de deficiências causadas por doenças genéticas em municípios da Paraíba. 2011. 25 f. TCC (Graduação) - Curso de Ciências Biológicas, Universidade Estadual da Paraíba, Campina Grande, 2011. 